Published as :: Arbi, M., Khedhiri, L., Hamdi, A., Ferretti, V., Lefebvre, F., Jelsch, C., \& Nasr, CB.

(2019). Synthesis, structural elucidation, spectroscopic and Hirshfeld surface analysis of a new organic cyclohexaphosphate,(C12H19N2) 4 (Li) 2 (P6O18)(H2O) 4. Chemical Data Collections, 20, $100188 . \quad$ doi.org/10.1016/j.cdc.2019.100188

\title{
Synthesis, structural elucidation, spectroscopic and Hirshfeld surface analysis of a new organic cyclohexaphosphate, $\left(\mathrm{C}_{12} \mathrm{H}_{19} \mathrm{~N}_{2}\right)_{4}(\mathrm{Li})_{2}\left(\mathrm{P}_{6} \mathrm{O}_{18}\right)\left(\mathrm{H}_{2} \mathrm{O}\right)_{4}$
}

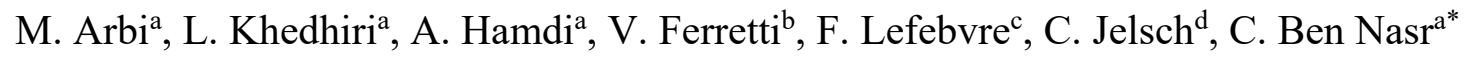

${ }^{a}$ Laboratoire de Chimie des Matériaux, Faculté des Sciences de Bizerte, 7021 Zarzouna, Université de Carthage, Tunisie.

${ }^{\mathrm{b}}$ Department of Chemical and Pharmaceutical Sciences and Center for Structural Diffractometry, via Fossato di Mortara 17, I-44121 Ferrara, Italy.

${ }^{\mathrm{c}}$ Laboratoire de Chimie Organométallique de Surface (LCOMS), Ecole Supérieure de Chimie Physique Electronique, 69626 Villeurbanne Cedex, France.

${ }^{\mathrm{d}} \mathrm{CRM}^{2}$, CNRS, Institut Jean Barriol, Université de Lorraine, Vandoeuvre les Nancy CEDEX, France.
}

Corresponding e-mail: cherifbennasr48@gmail.com

\begin{abstract}
The synthesis and properties of the new tetrakis [1-(2,3-dimethylphenyl)piperazinium] bis(lithium-ion) cyclohexaphosphate tetrahydrate, $\left(\mathrm{C}_{12} \mathrm{H}_{19} \mathrm{~N}_{2}\right)_{4}(\mathrm{Li})_{2}\left(\mathrm{P}_{6} \mathrm{O}_{18}\right)\left(\mathrm{H}_{2} \mathrm{O}\right)_{4} \quad$ are reported. This compound was characterized by X-ray diffraction (XRD), spectroscopy (NMR and FT-IR) and Hirshfeld analysis. Electronic properties such as HOMO and LUMO energies
\end{abstract}


were derived. The solved molecular structure of $\left(\mathrm{C}_{12} \mathrm{H}_{19} \mathrm{~N}_{2}\right)_{4}(\mathrm{Li})_{2}\left(\mathrm{P}_{6} \mathrm{O}_{18}\right)\left(\mathrm{H}_{2} \mathrm{O}\right)_{4}$ revealed that the atomic arrangement of (I) is built up from alternated organic and inorganic species. Adjacent $\mathrm{P}_{6} \mathrm{O}_{18}$ rings are linked via corner-sharing by $\mathrm{LiO}_{5}$ pseudo-square pyramids, generating anionic layers parallel to the (001) crystallographic plane at $z=1 / 2$ with the organic groups located between them. The 3D-supramolecular network is stabilized by N-H...O and $\mathrm{O}-\mathrm{H} . . . \mathrm{O}$ hydrogen bonds, by $\mathrm{O}^{\delta-} \ldots \mathrm{Li}^{+}$ionic bridges and also by extensive hydrophobic interactions involving the organic cations as checked by Hirshfeld surface analysis. The van der Waals contacts play a key role in the consolidation of the packing of the structure of $\left(\mathrm{C}_{12} \mathrm{H}_{19} \mathrm{~N}_{2}\right)_{4}(\mathrm{Li})_{2}\left(\mathrm{P}_{6} \mathrm{O}_{18}\right)\left(\mathrm{H}_{2} \mathrm{O}\right)_{4}$.

Keywords: Cyclohexaphosphate; X-ray diffraction analysis; Hirshfeld surface; Enrichment ratio; MAS-NMR spectroscopy.

\section{Rationale}

Inorganic-organic compounds provide a class of materials displaying interesting technological importance [1]. The ability to combine the properties of organic and inorganic compounds within one single compound leads to interesting crystal structures [2]. In these materials, the crystal packing is ensured by ionic bridges, hydrogen bonds and Vander Waals contacts. These non-covalent forces play a vital role in molecular recognition, selforganization of molecules and highly efficient and specific biological reactions associated with supramolecular chemistry [3]. In this area, the literature reports several cyclohexaphosphates of mixed cations (organic-lithium) which have been known and structurally characterized [4-8]. In this work, we report the preparation and the structural investigation of a new cyclohexaphosphate, $\left[\mathrm{C}_{12} \mathrm{H}_{19} \mathrm{~N}_{2}\right] 4 \mathrm{Li}_{2} \mathrm{P}_{6} \mathrm{O}_{18} .4 \mathrm{H}_{2} \mathrm{O}$, where the organic species are the piperazinium groups. Piperazine derivatives have wide range of applications in 
pharmaceuticals as antimalarial [9], anti-tuberculosis [10], antitumor [11], anticancer [12] and antiviral agents [13].

\section{Procedure}

\subsection{Chemical Preparation}

An aqueous solution of $\mathrm{H}_{6} \mathrm{P}_{6} \mathrm{O}_{18}(10 \mathrm{~mL}, 2 \mathrm{mmol})$ was added dropwise to $5 \mathrm{~mL}$ of an ethanolic solution of 1-(2,3-dimethlphenylpiperazine (4 mmol) purchased from SigmaAldrich. The resulting solution was stirred at room temperature for $30 \mathrm{~min}$ and allowed to stand over a week to give colorless prismatic crystals. The cyclohexaphosphoric acid $\mathrm{H}_{6} \mathrm{P}_{6} \mathrm{O}_{18}$, was produced from $\mathrm{Li}_{6} \mathrm{P}_{6} \mathrm{O}_{18} .6 \mathrm{H}_{2} \mathrm{O}$, prepared according to the procedure of Schülke and Kayser [14], through an ion-exchange resin in H-state (Amberlite IR 120). The obtained compound, is stable in air at room temperature for more than several months. A yield of $80 \%$ was calculated for $\left[\mathrm{C}_{12} \mathrm{H}_{19} \mathrm{~N}_{2}\right]_{4} \mathrm{Li}_{2} \mathrm{P}_{6} \mathrm{O}_{18} .4 \mathrm{H}_{2} \mathrm{O}$.

\subsection{X-ray single crystal structural analysis}

Suitable crystals of $\left(\mathrm{C}_{12} \mathrm{H}_{19} \mathrm{~N}_{2}\right)_{4}(\mathrm{Li})_{2}\left(\mathrm{P}_{6} \mathrm{O}_{18}\right)\left(\mathrm{H}_{2} \mathrm{O}\right)_{4}$ were selected and mounted on a Nonius Kappa CCD diffractometer, using Mo radiation ( $\lambda=0.71073 \AA$ ). Intensities were collected at $295 \mathrm{~K}$ and were corrected for Lorentz, polarization and absorption effects [15]. The structure was solved by direct methods with the SIR97 suite of programs [16] and refinement was performed on $F^{2}$ by full matrix least-squares methods with all non-H atoms anisotropic with SHELXL2014/7 [17]. The H atoms were included on calculated positions, riding on their carrier atoms, apart from those bound to $\mathrm{N}$ and $\mathrm{O}$ atoms, located in the difference Fourier map and refined isotropically. All calculations were performed using the WINGX system of programs [18]. The drawings were made with Diamond [19]. Some data collection parameters and results of the structure determination are given in Table 1. 


\subsection{NMR and IR measurements}

The NMR powder spectra were recorded on a solid-state high-resolution Bruker Avance-500 spectrometer operating at $125.81 \mathrm{MHz}$ for ${ }^{13} \mathrm{C}, 50.50 \mathrm{MHz}$ for ${ }^{15} \mathrm{~N}$ and 202.51 $\mathrm{MHz}$ for ${ }^{31} \mathrm{P}$ with a classical $4 \mathrm{~mm} \mathrm{BB} / 1 \mathrm{H}$ dual MAS probe allowing spinning rates up to 10 $14 \mathrm{kHz} .{ }^{13} \mathrm{C},{ }^{15} \mathrm{~N}$ and ${ }^{31} \mathrm{P}$ NMR chemical shifts are given relative to external tetramethylsilane, neat nitromethane and 85 wt. \% phosphoric acid, respectively (precision $0.5 \mathrm{ppm}$ ). The ${ }^{7} \mathrm{Li}$ MAS NMR spectrum was recorded on a Bruker Avance-300 spectrometer operating at 116.75

MHz. For ${ }^{13} \mathrm{C}$ and ${ }^{15} \mathrm{~N}$, the spectra were recorded by use of cross polarization (CP) from protons (contact time $2 \mathrm{~ms}$ ). Before recording the spectra, it was checked that there was a sufficient delay between the scans allowing a full relaxation of the protons, typically $30 \mathrm{~s}$ in the present case. For ${ }^{31} \mathrm{P}$, the isotropic chemical shift values $\left(\delta_{\text {iso }}\right)$ of the three NMR species were determined from the position of the peaks that did not change in the spectra taken with different spinning rates. The analysis of the ${ }^{31} \mathrm{P}$ MAS-NMR spectrum was carried out by using the Bruker program WINFIT [20]. The intensities of the sidebands were computed by the method of Herzfeld and Berger [21]. The chemical shift anisotropy $\left(\Delta \delta_{\mathrm{CS}}\right)$ and the asymmetric parameter $(\eta)$ for the three NMR components were then determined. The IR spectra were recorded in the 4000-400 $\mathrm{cm}^{-1}$ range with a "Perkin-Elmer FTIR" spectrophotometer1000 using samples dispersed in spectroscopically pure $\mathrm{KBr}$ pressed into a pellet.

\section{Data, value and validation}

\subsection{Crystal structure analysis}

An ORTEP view of the molecular structure of (I) with the atom numbering scheme is shown in Fig. 1 while the atomic arrangement is shown in Figs. 2 and 3. The asymmetric unit of (I) includes one-half of a $\mathrm{P}_{6} \mathrm{O}_{18}{ }^{6-}$ anion lying on an inversion center $(1 / 2,0,1 / 2)$, one $\mathrm{Li}^{+}$ cation, two water molecules out of which one $(\mathrm{O} 1 \mathrm{~W})$ is coordinated to the lithium cation and 
two 1-(2,3-dimethylphenyl) piperazinium cations (Fig. 1). The $\mathrm{P}_{6} \mathrm{O}_{18}{ }^{6-}$ oxo-anion has a chairshaped 12-membered ring. All phosphorus and oxygen atoms are found in general positions. Due to the inversion symmetry, the $\mathrm{P}_{6} \mathrm{O}_{18}$ moiety is built up by three independent $\mathrm{PO}_{4}$ tetrahedra. The P-P-P angles of 96.03(2), 126.89(2) and 137.05(2) ${ }^{\circ}$ show that the rings are significantly distorted from the ideal three-fold symmetry; the total puckering amplitude $Q$, measuring the overall degree of puckering according to Cremer and Pople [22], is 1.8883(3) A. It should be noted that these large deviations are commonly observed in cyclohexaphosphates with a ring of low local symmetry $[\mathbf{2 3}, \mathbf{2 4}]$, as in the title compound. For example, the P-P-P angles in $\mathrm{Cs}_{6} \mathrm{P}_{6} \mathrm{O}_{18.6} 6 \mathrm{H}_{2} \mathrm{O}$ [25], ranging from 93.2 to $145.5^{\circ}$, exhibit the largest distortion measured up to now. The great flexibility of the 12-membered $\mathrm{P}_{6} \mathrm{O}_{18}$ rings can explain the discrepancy between large rings and the small ones.

The P-O and P-P distances and the P-O-P or O-P-O angles are shown in Table 2. The average values of the distortion indices [26] are $(\mathrm{DI}(\mathrm{PO})=0.042, \mathrm{DI}(\mathrm{OPO})=0.040$ and $\mathrm{DI}(\mathrm{OO})=0.013$ (Table 3). These geometrical characteristics of the $\mathrm{PO}_{4}$ tetrahedra show, in spite of the P-P-P angles deformation, no significant difference in deviation from those observed in other cyclohexaphosphates having the same internal symmetry such as in $\left(\mathrm{C}_{6} \mathrm{H}_{7} \mathrm{ClN}\right)_{6} \mathrm{P}_{6} \mathrm{O}_{18} .0 .5\left(\mathrm{H}_{2} \mathrm{O}\right)[27]$ and $\left(\mathrm{C}_{9} \mathrm{H}_{14} \mathrm{~N}\right)_{4}\left(\mathrm{H}_{3} \mathrm{O}\right)_{2}\left(\mathrm{P}_{6} \mathrm{O}_{18}\right)[28]$.

The lithium cation is five-coordinated, being coordinated to one water molecule O1W and four $\mathrm{O}$ atoms $\mathrm{O}(\mathrm{E})$ belonging to two $\mathrm{P}_{6} \mathrm{O}_{18}{ }^{6-}$ ring anions (Fig. 2c). The geometrical features of $\mathrm{LiO}_{5}$ pseudo-square pyramids are in accordance with values observed in $\mathrm{Li}_{6} \mathrm{P}_{6} \mathrm{O}_{18} .10 \mathrm{H}_{2} \mathrm{O}$ [29]. The Li-O distances range from 1.956(4) to 2.406(4) $\AA$ (Table 2). The smallest distance between two pyramidal centers is 3.003(2) $\AA$.

Two organic entities $\left[\mathrm{C}_{12} \mathrm{H}_{19} \mathrm{~N}_{2}\right]^{+}$coexist in the asymmetric unit assuring the electric neutrality of the total complex. The benzyl rings (C5-C10) and (C17-C22) are essentially planar with a root mean square (r.m.s.) deviation of 0.0047 and $0.0052 \AA$, respectively and are 
orientated at an angle of $29.8(5) / 30.2(3)^{\circ}$ with respect to the piperazine rings. Both piperazine rings $(\mathrm{N} 1-\mathrm{N} 2 / \mathrm{C} 1-\mathrm{C} 4)$ and $(\mathrm{N} 3-\mathrm{N} 4 / \mathrm{C} 13-\mathrm{C} 16)$ adopt a chair conformation. The puckering parameters for $\left[\mathrm{C}_{12} \mathrm{H}_{19} \mathrm{~N}_{2}(1)\right]^{+}$are QT $=0.577$ (2) $\AA, \theta=0.7(2)^{\circ}$ and $\varphi=326(2)$ and, for $\left[\mathrm{C}_{12} \mathrm{H}_{19} \mathrm{~N}_{2}(2)\right]^{+}: \mathrm{QT}=0.557$ (2) $\AA, \theta=0.6(2)^{\circ}$ and $\varphi=332$ (2) [22]. The atoms N1, $\mathrm{N} 2, \mathrm{~N} 3$ and N4 are deviating by -0.683 (2), 0.657 (2) and -0.673 (2), 0.557 (2) Å respectively from the least-squares plane defined by the remaining atoms in each ring. The interatomic bond lengths $(\mathrm{C}-\mathrm{C}, \mathrm{N}-\mathrm{C})$ and angles $(\mathrm{C}-\mathrm{C}-\mathrm{C}, \mathrm{C}-\mathrm{N}-\mathrm{C})$ (Table 4) do not show a significant deviation from those reported in the related compound bis[1-(2,3dimethylphenyl)piperazine1,4-diium] bis(oxonium) cyclohexaphosphate dihydrate [30].

The $\mathrm{P}_{6} \mathrm{O}_{18}{ }^{6-}$ anions are connected through corner sharing by lithium cations and the two hydrogen atoms of the water molecule $\mathrm{O} 1 \mathrm{~W}$ to form a hetero-anion of formula $\left[\mathrm{Li}_{2} \mathrm{P}_{6} \mathrm{O}_{18} \cdot \mathrm{H}_{2} \mathrm{O}\right]^{4-}$ extending along the $a$ direction at $y=0$ as shown in Fig. 2-b. The remaining water molecules, $\mathrm{O} 2 \mathrm{~W} 1$ and $\mathrm{O} 2 \mathrm{~W} 2$, with an occupancy ratio of $1 / 2$ for each one, bridge the anionic rings through $\mathrm{O}-\mathrm{H} \ldots \mathrm{O}$ hydrogen bonds to form 2-D layers parallel to the (001) crystallographic plane as shown in Fig. 2-a and located at $z=1 / 2$ (Fig. 3). The anchorage of the organic cations $\left[\mathrm{C}_{12} \mathrm{H}_{19} \mathrm{~N}_{2}\right]^{+}$onto successive layers is made by $\mathrm{N}-\mathrm{H} \ldots \mathrm{O}$ bonds involving the hydrogen atoms of the $-\mathrm{NH}_{2}$ groups thus ensuring the interconnection between layers, and giving rise to a three-dimensional network (Fig 3-a, 3-b). The geometrical features of the Hbonds are listed in Table 5. All these hydrogen bonds, van der Waals, and electrostatic interactions between organic cations and cyclohexaphosphate anions increase the stability of the crystal structure.

\subsection{Crystal contacts}

The Hirshfeld surface was generated using MoProViewer [31] around the different entities of the title compound. Hirshfeld surfaces are produced through the partitioning of 
space within a crystal where the ratio of promolecule to procrystal electron densities is equal to 0.5 . As the asymmetric unit contains only one half of cyclohexaphosphate moiety, the Hirshfeld calculation was done on two copies of the asymmetric unit containing one $\mathrm{P}_{6} \mathrm{O}_{18}$, four $\mathrm{C}_{12} \mathrm{H}_{19} \mathrm{~N}_{2}$, two lithium and two copies of the two water molecules. In order to have integral surfaces, symmetry related molecules were chosen in the crystal packing that are not in contact with each other.

The Hirshfeld surface analysis was also performed using the Crystal Explorer 3.1 software [32] and the TONTO [33] system. In the crystal structure, intermolecular interactions were analyzed for two copies of the asymmetric unit using $2 \mathrm{D}$ fingerprint maps (Fig. 4). The 2D fingerprint plots can be decomposed to highlight a particular pair of atoms in close contact. The contributions from the main interaction types $(\mathrm{H} . . \mathrm{H}, \mathrm{C} \ldots \mathrm{H}, \mathrm{O} \ldots \mathrm{H}$, O...Li) are shown in the fingerprint plots (Fig. 4). The atoms in closest proximity are those found in the $\mathrm{H} \ldots \mathrm{H}$ and $\mathrm{O} \ldots \mathrm{H}$ contacts.

The enrichment ratios [34] of contacts between the different chemical species were computed with MoProViewer in order to highlight which contacts are over-represented and are likely to represent energetically strong interactions and the driving force in crystal formation . Globally, hydrogen represents the majority of chemical species (55\%) present on the Hirshfeld surface, followed by oxygen and carbon (Table 6). The hydrophobic atoms Hc and $\mathrm{C}$ constitute close to half of the molecular surface.

After the hydrophobic Hc...Hc contacts, the Ho/n...O hydrogen bonds involving the hexacyclophosphate, the water molecules and the $\mathrm{NH}_{2}{ }^{+}$group are the most abundant polar interaction types and are quite enriched at $E=2.7$ (Table 6). The O...Li attractive ionic interaction is the most enriched with $E=3.2$ and the lithium cation is almost exclusively interacting with five oxygen atoms (Tables 6 and 2). The contacts made by the phosphorous 
atoms are presumably mostly the consequence of the interactions made by the $\mathrm{P}_{6} \mathrm{O}_{18}$ oxygen atoms.

The C...Hc and Hc...Hc contacts constitute a significant part of the interaction surface and all hydrophobic contacts types involving $\mathrm{C}$ and $\mathrm{Hc}$ are over-represented. The Hc... C contacts are notably enriched at $E=1.84$ as the crystal shows some C-H... interactions which are considered as weak hydrogen bonds. The C5-C10 six-membered aromatic ring interacts with $\mathrm{CH}_{3}$ and $\mathrm{CH}_{2}$ groups on either side (Fig. 5). The C17-C22 C6 ring is also involved in some C...C $\pi$ stacking.

The weak Hc...O hydrogen bonds are quite under-represented $(E=0.6)$ due to competition with the $\mathrm{Hn} / \mathrm{o} \ldots \mathrm{O}$ and $\mathrm{Li} . . . \mathrm{O}$ stronger electrostatic interactions.

The two independent organic cations show different torsion angles between the two rings $\left(\mathrm{C} 10-\mathrm{C} 5-\mathrm{N} 1-\mathrm{C} 1=16.00(2)^{\circ}\right.$ while $\left.\mathrm{C} 22-\mathrm{C} 17-\mathrm{N} 3-\mathrm{C} 13=37(2)^{\circ}\right)$. They show contact types with their environment which are globally similar as the contacts $C$ xy of the two cations are $94 \%$ correlated. When the enrichment ratios are compared, the correlation is only $31 \%$. Fig. 5 shows the Hirshfeld surface of the two independent organic molecules colored according to their local contact type. The two molecules display locally different contact types on their surface, with the exception of the region above the C6 aromatic ring which is involved in extensive C...Hc interactions in both cases.

\subsection{HOMO-LUMO analysis}

The frontier molecular orbitals determine the way of a molecule interacts with other entities and helps to determine its kinetic stability and chemical reactivity. HOMO-LUMO orbitals were computed for the organic molecule by the DFT- B3LYP/6-31+G* method. Three different calculations were made, the two molecules of the asymmetric unit for which the $\mathrm{C}$ and $\mathrm{N}$ positions were taken from the crystal data and a full optimization of all atoms. 
These calculations were made with the Gaussian 09 program and the results are displayed in

Fig. 6. The calculated HOMO and LUMO orbitals are shown in the order: total optimization, Ligand 1 and Ligand 2. In the three cases quite the same results were obtained: The highest occupied molecular orbital (HOMO) is located mainly on the aromatic ring and on the nitrogen atom which is linked to it with a calculated energy of $-9.217 \mathrm{eV}$, and the LUMO is concentrated on the $\mathrm{NH}_{2}$ group with a calculated energy is $-4.755 \mathrm{eV}$. The large energy gap between the HOMO and LUMO orbitals $(4.46 \mathrm{eV})$ shows that the molecule is kinetically stable and has a small chemical reactivity $[36,37]$. The energy distributions of the different are given in Fig. 7 and are also quite similar in the three cases, showing that there is no high constraint in the crystal.

\subsection{Molecular Electrostatic Potential Analysis}

The molecular electrostatic potential of the title compound has been computed at the B3LYP/6-31+G* level and is shown in Fig. 8. Moreover, blue and red colors indicate the positive and negative potentials, respectively. As it can be seen from Fig. 8, the electrostatic potential maps are color-coded and are subdivided into many regions where those various colors are used to identify different potentials. Intermediate potentials are assigned to colors according to the following color spectrum: red $<$ orange $<$ yellow $<$ green $<$ blue. As seen from Fig. 8, the red region is located around the aromatic ring, while the blue region is around the $\mathrm{NH}_{2}$ group of the piperazine molecule.

\subsection{NMR results}

The ${ }^{13} \mathrm{C}$ CP-MAS NMR spectrum of $\left(\mathrm{C}_{12} \mathrm{H}_{19} \mathrm{~N}_{2}\right)_{4}(\mathrm{Li})_{2}\left(\mathrm{P}_{6} \mathrm{O}_{18}\right)\left(\mathrm{H}_{2} \mathrm{O}\right)_{4}$ is shown on Fig. 9. The spectrum recorded with a contact time of $2 \mathrm{~ms}$ shows the existence of three sets of peaks at $10-20 \mathrm{ppm}$, related to the methyl groups, $40-50 \mathrm{ppm}$, corresponding to the piperazine carbon atoms and in the area of the aromatic carbons, between 110 and $150 \mathrm{ppm}$, 
in agreement with the organic structure. However, the presence of three peaks at 10.2, 15.9 and $20.6 \mathrm{ppm}$ with an intensity ratio 1:1:2, corresponding to four methyl groups, clearly indicates the presence of two organic molecules in the asymmetric unit, in agreement with the X-ray results.

To identify the aromatic carbons which are not bound to protons, we have recorded the spectrum with a very short contact time $(100 \mu \mathrm{s})$. The two spectra are shown in Fig. 10. Obviously the 5 peaks on the left are not related to protons because they have a much lower intensity when the contact time is very low. This result is helpful for the attribution of the peaks to the various carbon atoms of the two organic molecules of the asymmetric unit.

The 2D HETCOR carbon-proton spectrum is shown in Fig. 11. It exhibits three families of correlations corresponding to the methyl groups, the $\mathrm{CH}_{2}$ groups of the piperazine ring and the aromatic carbon atoms linked to protons (the spectrum was recorded with a short contact time, $200 \mu \mathrm{s}$ ). This spectrum confirms also that the five peaks in the range 129-150 ppm of the ${ }^{13} \mathrm{C}$ CP-MAS NMR spectrum correspond to the aromatic carbon atoms not bonded to the hydrogen atoms, as they do not show any correlation.

The solid state ${ }^{31} \mathrm{P}$ spectrum of the sample is formed by three components (Fig. 12) corresponding to the three crystallographically independent phosphorus atoms. As the chemical environments of all P-atoms are similar in the cyclohexaphosphate, resolved components must correspond to different crystallographic sites occupied by P-atoms. On the other hand, distortions of the polyhedra are responsible for the observed chemical shift anisotropies and for the detection of the spinning side band patterns covering important regions of the ${ }^{31} \mathrm{P}-\mathrm{NMR}$ spectra. Spectral regions occupied by these bands are proportional to tetrahedral distortions.

The ${ }^{15} \mathrm{~N}$ CP-MAS NMR spectrum of the title compound, shown in Fig. 13, is also in good agreement with the X-ray structure. Indeed, it exhibits four well-defined resonances 
corresponding to the four crystallographically independent nitrogen atoms, in agreement with two organic cations in the unit cell.

The solid state ${ }^{7} \mathrm{Li}$ spectrum of the sample is formed by only one peak with its corresponding satellite spinning bands spaced at equal intervals, indicating some anisotropy of chemical shift (Fig. 14-a). This result is consistent with the presence of only one lithium site in the asymmetric unit of the compound as revealed by single crystal X-ray diffraction. Fig. 14-b shows that the linewidth is larger when the spectrum is recorded without decoupling. This is due to the coupling of lithium with the hydrogen atoms of the water molecules coordinated to it.

Theoretical calculations were undertaken in order to assign the NMR resonances to the different crystallographic non-equivalent carbon atoms of the unit cell. The chemical shifts calculations were made on the organic molecules only. X-ray diffraction data give C-H or N$\mathrm{H}$ distances which are too small compared to what is usually observed (typically below 0.1 $\mathrm{nm}$ ) due to the fact that this method is not sensitive to the nuclei but to the electrons and so gives values corresponding to distances between the barycenters of electronic charges. As a consequence, the positions of the hydrogen atoms were first optimized with the B3LYP/6$31+\mathrm{G}^{*}$ method, the other atoms being frozen. Then, the absolute chemical shifts were calculated using the GIAO method. Finally, the calculated values were calibrated relative to tetramethylsilane with $\delta_{\exp }=0 \mathrm{ppm}$. The atoms are labeled as depicted below:

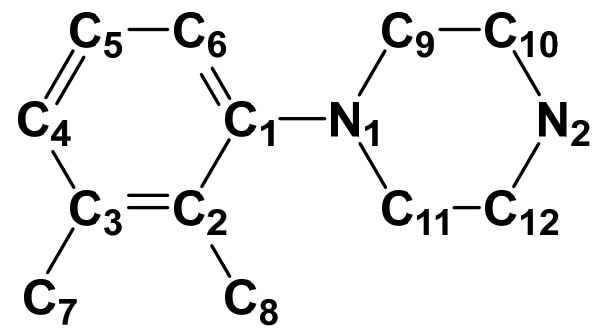

The results are listed on Table 7. Clearly, there is a very good agreement between the experimental and the theoretical values, allowing unambiguously the attribution of the 
different NMR signals, even if the calculated values for the isotropic chemical shifts are sometimes far away from the experimental ones.

\subsection{Vibrational FTR-IR spectroscopy}

The infrared spectrum (Fig. 15) shows a broad band centered at $3390 \mathrm{~cm}^{-1}$ which is assigned to the $\mathrm{O}-\mathrm{H}$ and $\mathrm{N}-\mathrm{H}$ stretching vibrations. Its broadness is indicative of the presence of hydrogen bonds in this compound as evidenced by XRD investigation. The lowering of wavenumbers can be explained by the involvement of the secondary amine $(-\mathrm{NH})$ in $\mathrm{H}$ bonding interactions [38]. Asymmetric and symmetric $\mathrm{C}-\mathrm{H}$ stretching vibrations occur in the region between 3025 and $2842 \mathrm{~cm}^{-1}$. The observed bands in the $\left[1650-1350 \mathrm{~cm}^{-1}\right]$ region are due to the bending vibrations of $\mathrm{O}-\mathrm{H}, \mathrm{CH}_{2}$ and $\mathrm{NH}_{2}$ [39]. Various strong stretching and bending vibration bands, observed in the range of $1350-660 \mathrm{~cm}^{-1}$, are characteristics of the cyclohexaphosphoric ring [40]. Indeed, the asymmetric and symmetric stretching vibrations of $v_{\text {as }}(\mathrm{OPO})^{-}$and $v_{\mathrm{s}}(\mathrm{OPO})^{-}$are found in the $1350-1180 \mathrm{~cm}^{-1}$ and $1180-1060 \mathrm{~cm}^{-1}$ ranges, respectively. Those which appear in the $1060-950 \mathrm{~cm}^{-1}$ and $850-660 \mathrm{~cm}^{-1}$ regions are attributed to $v_{\mathrm{as}}(\mathrm{POP})$ and $v_{\mathrm{s}}(\mathrm{POP})$ respectively. In the assignment of these bands, a special caution must be paid because of their overlapping with stretching $v(\mathrm{C}-\mathrm{N})$ and twisting $\tau\left(-\mathrm{CH}_{2}\right)$ modes. Wavenumbers below $600 \mathrm{~cm}^{-1}$ are related to the $\mathrm{P}_{6} \mathrm{O}_{18}$ ring bending vibrations.

\section{Conclusion}

The use of the protonated 1-(2,3-dimethlphenylpiperazine $\left(\mathrm{C}_{12} \mathrm{H}_{19} \mathrm{~N}_{2}\right)^{+}$as organic cation in the cyclohexaphosphate matrix leads to a new organic cyclohexaphosphate crystal with the chemical formula $\left(\mathrm{C}_{12} \mathrm{H}_{19} \mathrm{~N}_{2}\right)_{4}(\mathrm{Li})_{2}\left(\mathrm{P}_{6} \mathrm{O}_{18}\right)\left(\mathrm{H}_{2} \mathrm{O}\right)_{4}$. Crystal structure of this compound was found to be built by layers of $\left[(\mathrm{Li})_{2}\left(\mathrm{P}_{6} \mathrm{O}_{18}\right)\left(\mathrm{H}_{2} \mathrm{O}\right)_{4}\right]^{4-}$ parallel to the $(001)$ crystallographic plane and located at $z=1 / 2$. The two independent organic molecules form, between these layers, two planes where the charged $>\mathrm{NH}^{+}$groups are facing, on each side, the inorganic part. The organic cations perform the three dimensional cohesion mainly through hydrophobic 
interactions as well as strong $\mathrm{N}-\mathrm{H} \ldots \mathrm{O}$ and a few weak $\mathrm{C}-\mathrm{H} \ldots \mathrm{O}$ hydrogen bonds with the water and $\mathrm{C}_{6} \mathrm{H}_{18}$ moieties. The inorganic parts perform mostly strong N/O-H...O hydrogen bonds and Li...O electrostatic bridges to stabilize the three-dimensional network.

NMR signals are in full agreement with the crystallographic data. The theoretical calculations results are in agreement with the experimental geometric parameters.

\section{Acknowledgment}

The authors are grateful to the Tunisian Ministry of Higher Education and Scientific Research for financial support.

\section{Supplementary data}

Crystallographic data for the structural analysis have been deposited at the Cambridge Crystallographic Data Centre, CCDC No 1551864. These data can be obtained free of charge via http://www.ccdc.cam.ac.uk/conts/retrieving.html, or from the CCDC, 12 Union Road, Cambridge, CB2 1EZ, UK: fax: (+44) 01223-336-033; e-mail: deposit@ccdc.cam.ac.

\section{References}

[1] D. N. Dybtsev, H. Chun, S. H. Yoon, D. Kim, K. Kim, (2004). J. Am. Chem. Soc., $126,32-33$

[2] D.W. Smith, (1976), Chem. Rev., 21, 93-158.

[3] B. H. Ye, X. M. Chem, G. Q. Xue, L. N. Ji, (1998), J. . Chem. Soc., Dalton Trans., 17, $2827-2832$.

[4] I. Ameur, S. Abid, S. S. Al-Deyab, M. Rzaigui. Acta Cryst. E69 (2013) m305-m306

[5] R. Bel Haj Salah, L. Khedhiri, M. Rzaigui, X-Ray Struct. Anal. Online. 26 (2010) 4546.

[6] L. Khedhiri, X-Ray Struct. Anal. Online. 20 (2004) x143-x144. 
[7] O. Amri, S. Abid, M. Rzaigui, Phosphorus Sulfur Silicon Relat. Elem, 184, (2009) 766-777.

[8] L. Khedhiri, V. Ferretti, C. Jelsch, M. Rzaigui, C. Ben Nasr, Journal of Molecular Structure 1134 (2017) 828-834

[9] K. Kaur, M. Jain, R. P. Reddy, R. Jain, (2010). Eur. J. Med. Chem. 45, 3245-3264.

[10] S. Eswaran, A. V. Adhikari, I. H. Chowdhury, N. K. Pal, K. D. Thomas, (2010), Eur. J. Med. Chem. 45, 3374-3383.

[11] L. C. Chou, M. T. Tsai, M. H. Hsu, S. H. Wang, T. D. Way, C. H. Huang, H. Y. Lin, K. Qian, Y. Dong, K. H. Lee, L. J. Huang, S. C. Kuo, (2010). J. Med. Chem. 53, $8047-8058$.

[12] Y. L. Chen, H. M. Hung, C. M. Lu, K. C. Li, C. C. Tzeng (2004). Bioorg. Med. Chem. 12, 6539-6546.

[13] R. V. Shingalapur, K. M. Hosamani, R. S. Keri, (2009). Eur. J. Med. Chem. 44, $4244-4248$.

[14] U. Schülke, R. Kayser (1985). Z. Anorg. Allg. Chem. 531, 167-175.

[15] R. H. Blessing, Acta Crystallogr., Sect. A , 1995, 51, 33

[16] A. Altomare, M. C. Burla, M. Camalli, G. L. Cascarano, C. Giacovazzo, A. Guagliardi, A. Grazia, G. Moliterni, G. Polidori, R. J. Spagna, SIR97: a new tool for crystal structure determination and refinement, J. App. Cryst. 32 (1999) 115-119.

[17] G. M Sheldrick, SHELXTL Version 2014/7. http://shelx.uniac.gwdg.de/SHELX/index.php.

[18] L. J. Farrugia, Win $G X$ suite for small-molecule single-crystal crystallography, J. Appl. Crystallogr. 32 (1999) 837-838

[19] K. Brandenburg (1998). Diamond Version 2.0 Impact GbR. Bonn, Germany.

[20] Bruker WINFIT Program’ Bruker Rep. 140 (1994) 43-46. 
[21] J. Herzfeld, A. L. Berger, J. Chem. Phys. 73 (1980) 6021-6030.

[22] D. Cremer, J. A. Pople, J. Amer. Chem. Soc. 97 (1975) 1354-1358

[23] L. Khedhiri, C. Ben Nasr, M. Rzaigui, F. Lefebre, Helv. Chim. Acta. 86 (2003) $2662-$ 2670.

[24] L. Khedhiri, R. Bel Haj salah, W. Belam, M. Rzaigui, Acta Cryst. E63 (2007) 22692271.

[25] M. T. Averbuch-Pouchot, A. Durif, Eur. J. Solid State Inorg. Chem. 28 (1991) 9-22.

[26] W. H. Baur. Acta Cryst. B30 (1974) 1195-1215

[27] L. Khedhiri, E. Jeanneau, F. Lefebvre, M. Rzaigui, C. Ben Nasr, J. Mol. Struct. 1105 (2016) $87-95$

[28] L. Khedhiri, E. Jeanneau, F. Lefebvre, M. Rzaigui, C. Ben Nasr, J. Chem. Sci. 128 (2016) 1037-1045

[29] T. Ben Chaabane, L. Smiri-Dogguy, J. Chem. Cryst. 29 (1999) 323-327

[30] I. Ameur, S. Abid, S. S Al-Deyab, M. Rzaigui, Acta Cryst. (2013). E69, o1145-o1146.

[31] B. Guillot, E. Enrique, L. Huder, C. Jelsch, Acta Cryst. A70 (2014) C279.

[32] S. K. Wolff, D. J. Grimwood, J. J. McKinnon, M. J. Turner, D. Jayatilaka, and M. A. Spackman, CRYSTAL-EXPLORER 3.0 (University of Western Australia, Perth, 2012).

[33] D. Jayatilaka, D. J. Grimwood, A. Lee, et al. TONTO, A System for Computational Chemistry (The University of Western Australia, 2005).

[34] C. Jelsch, S. Soudani, C. Ben Nasr, IUCr J. 2 (2015) 327 - 340.

[35] R. G. Parr, R.G. Pearson, J. Am. Chem. Soc. 105 (1983) 7512-7516.

[36] R. G. Pearson, Proc. Natl. Acad. Sci. USA 83 (1986) 8440-8441. 
[37] E. Lippmaa, M. Magi, A. Samoson, M. Tarmak, G. Engelhardt, A. R. Grimmer, J. Am. Chem. Soc., 102 (1980) 4889-4893.

[38] J.-Ha Choi, Inorg. Chim. Acta 362 (2009) 4231.

[39] (a) L.J. Bellamy, The Infrared Spectra of Complex Molecules, 2nd ed., John Wiley \& Sons, Inc, New -York, 1975; (b) R.M. Silverstein, F.X. Webster, D.J. Kiemle, Spectrometric Identification of Organic Compound, 7th ed., John Wiley \& Sons Inc, New York, 2005.

[40] C. Ben Nasr, M. Rzaigui, I. Sobrados, J. Sanz, J. Alloys Compd. 325 (2001) 102-108.

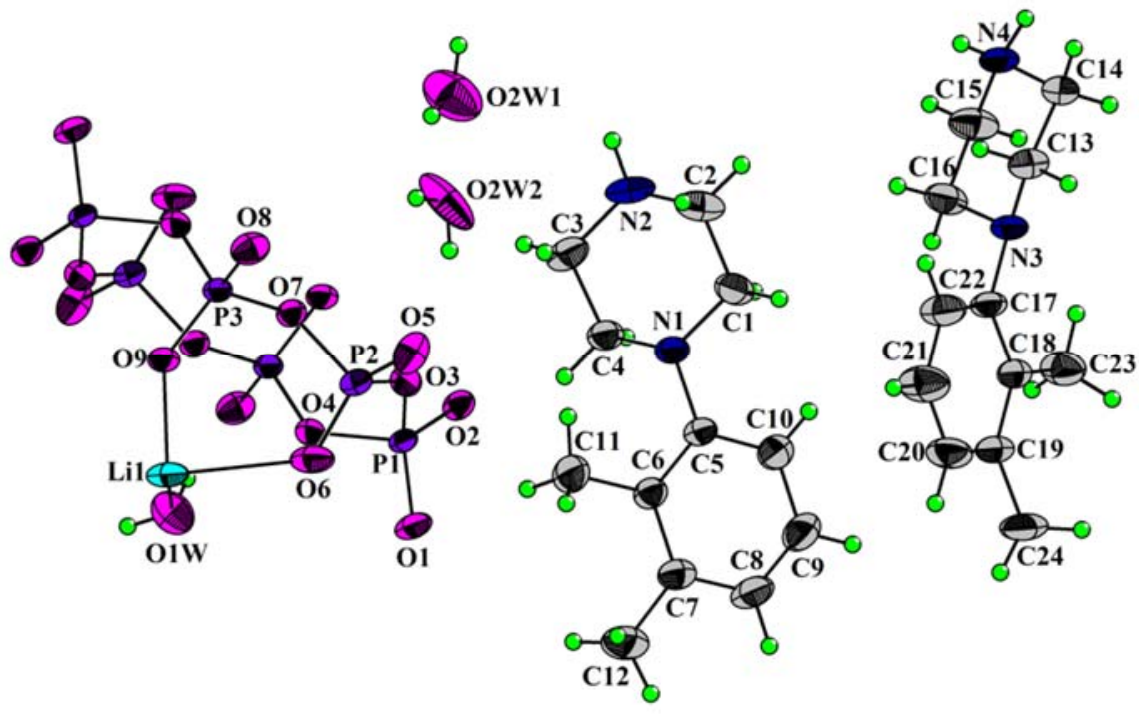

Fig. 1. ORTEP view of the $\left(\mathrm{C}_{12} \mathrm{H}_{19} \mathrm{~N}_{2}\right)_{4}(\mathrm{Li})_{2}\left(\mathrm{P}_{6} \mathrm{O}_{18}\right)\left(\mathrm{H}_{2} \mathrm{O}\right)_{4}$ asymmetric unit. Displacement ellipsoids are drawn at the $40 \%$ probability level and $\mathrm{H}$ atoms are shown as small spheres of arbitrary radii. 


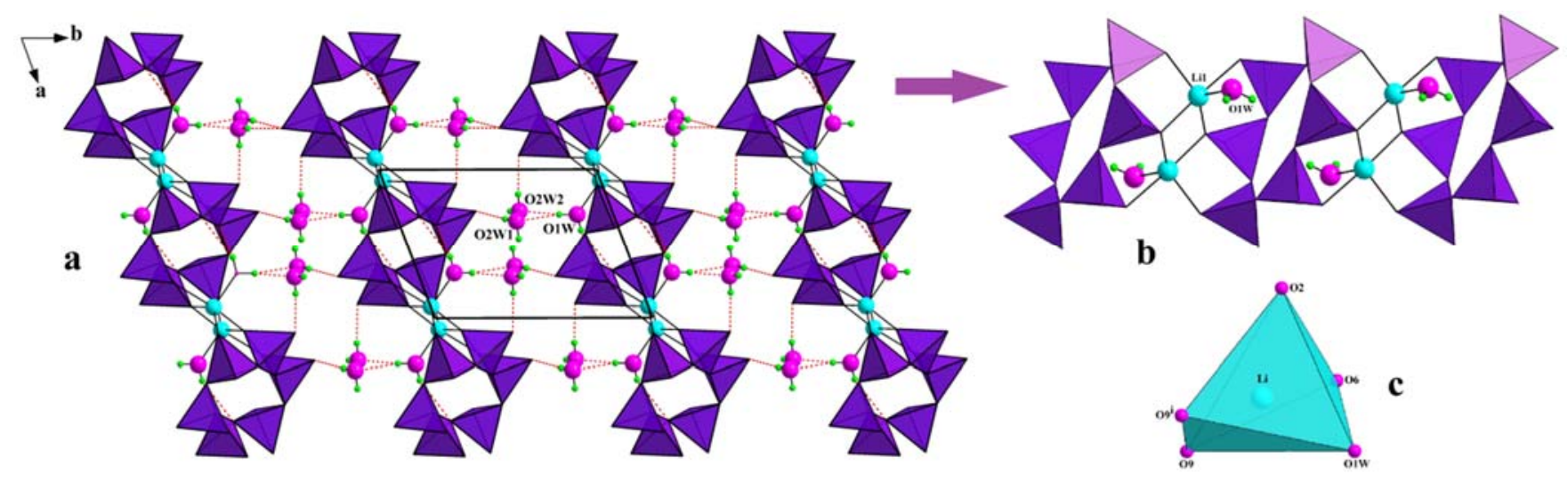

Fig. 2. (a) Projection along the $c$-axis, of an inorganic layer in the structure of

$\left(\mathrm{C}_{12} \mathrm{H}_{19} \mathrm{~N}_{2}\right)_{4}(\mathrm{Li})_{2}\left(\mathrm{P}_{6} \mathrm{O}_{18}\right)\left(\mathrm{H}_{2} \mathrm{O}\right)_{4}$. (b) hetero-anions of formula $\left[\mathrm{Li}_{2} \mathrm{P}_{6} \mathrm{O}_{18} \cdot \mathrm{H}_{2} \mathrm{O}\right]^{4-}$ (c)

Coordination of $\mathrm{LiO}_{5}$.
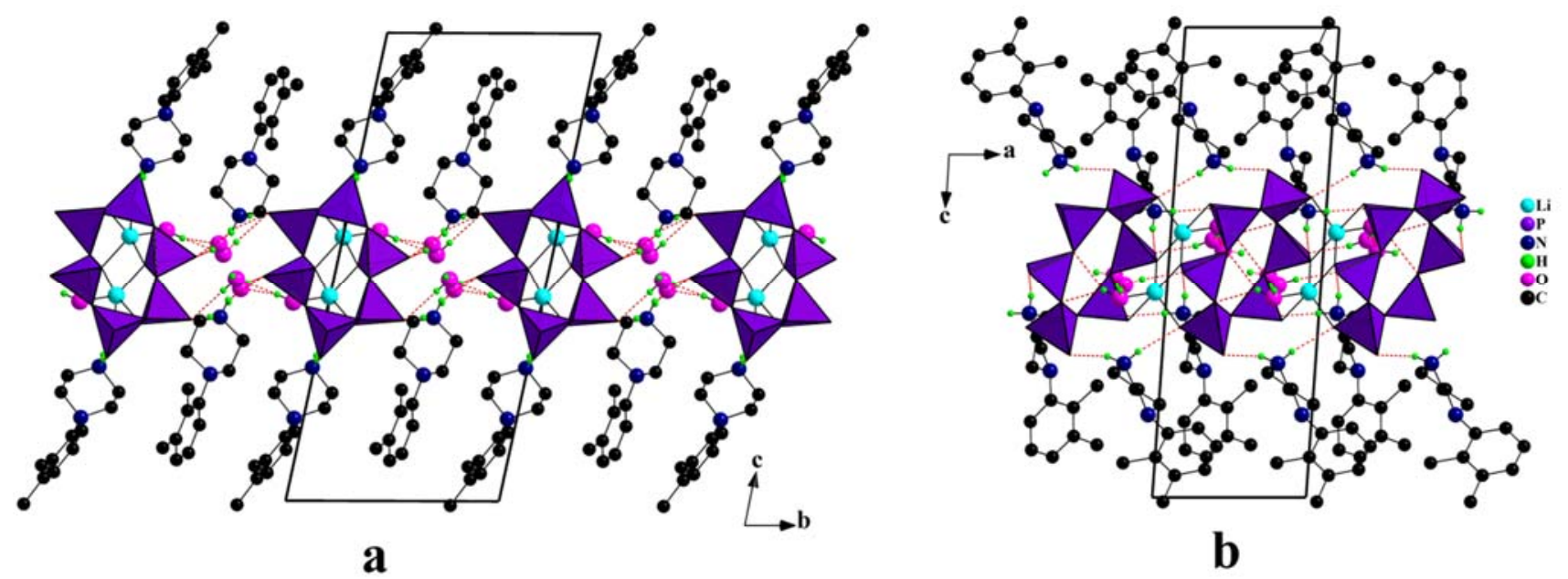

Fig. 3. Atomic arrangement of $\left(\mathrm{C}_{12} \mathrm{H}_{19} \mathrm{~N}_{2}\right)_{4}(\mathrm{Li})_{2}\left(\mathrm{P}_{6} \mathrm{O}_{18}\right)\left(\mathrm{H}_{2} \mathrm{O}\right)_{4}$, projected along $a$ and $b$-axis, showing the linkage between the different entities of the structure. 

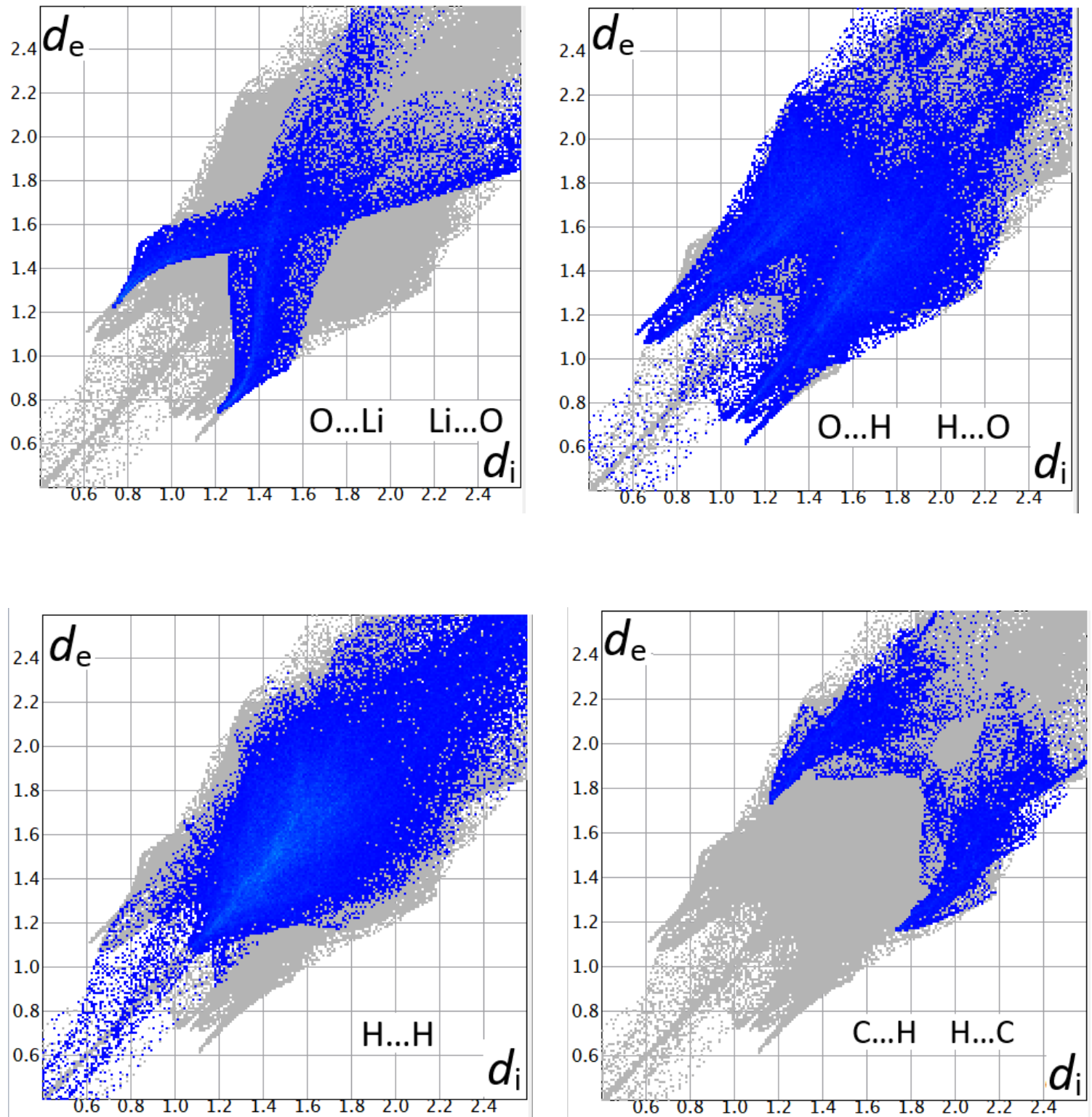

Fig. 4. 2D fingerprint plots of the title complex where areas of different intermolecular contacts are clearly shown; de and di are the distances to the nearest atom exterior and interior to the surface. 

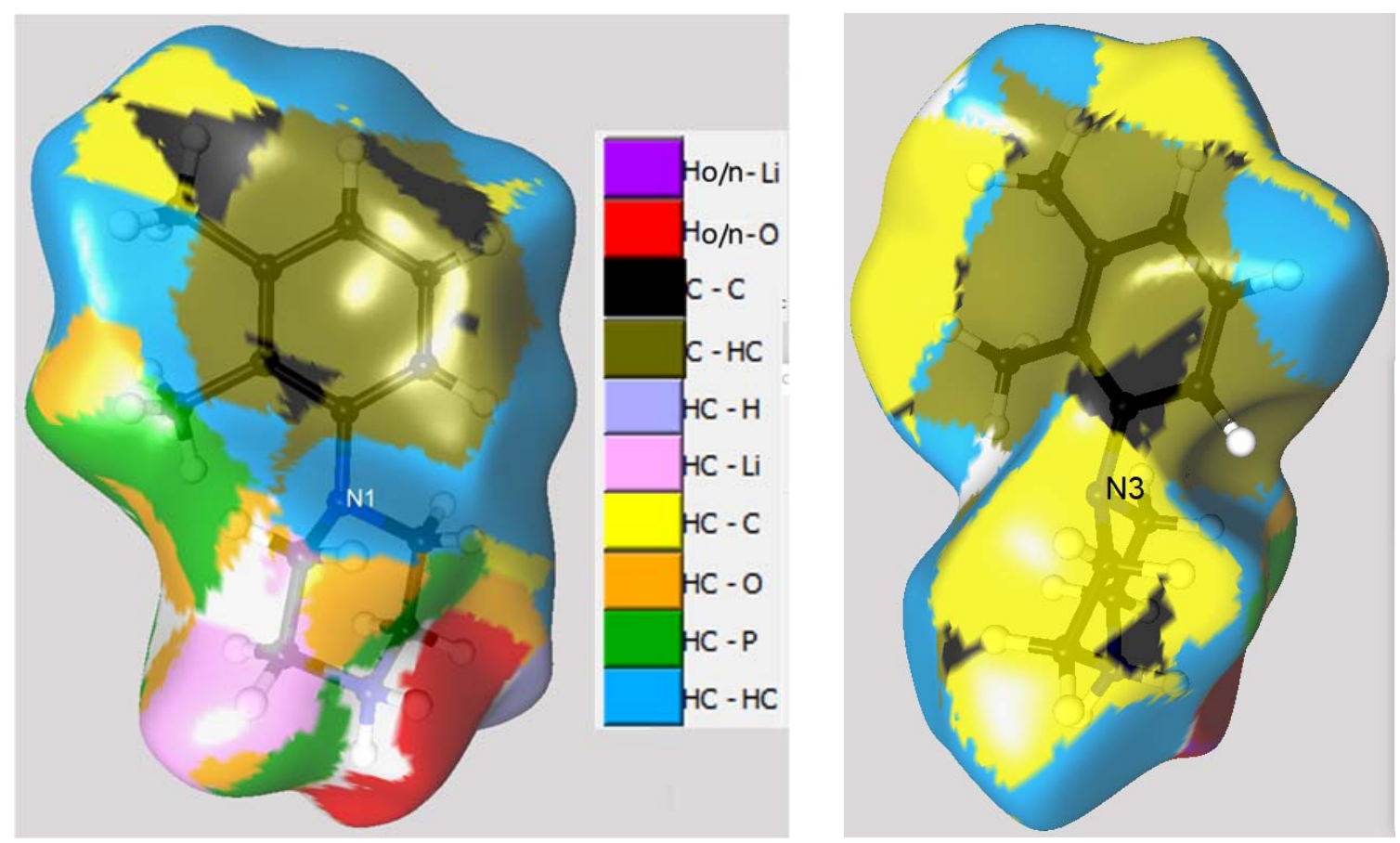

Fig. 5. View of the Hirshfeld surface around the two organic cations made with MoProViewer. Coloring of the surfaces is according to the local contact type. 


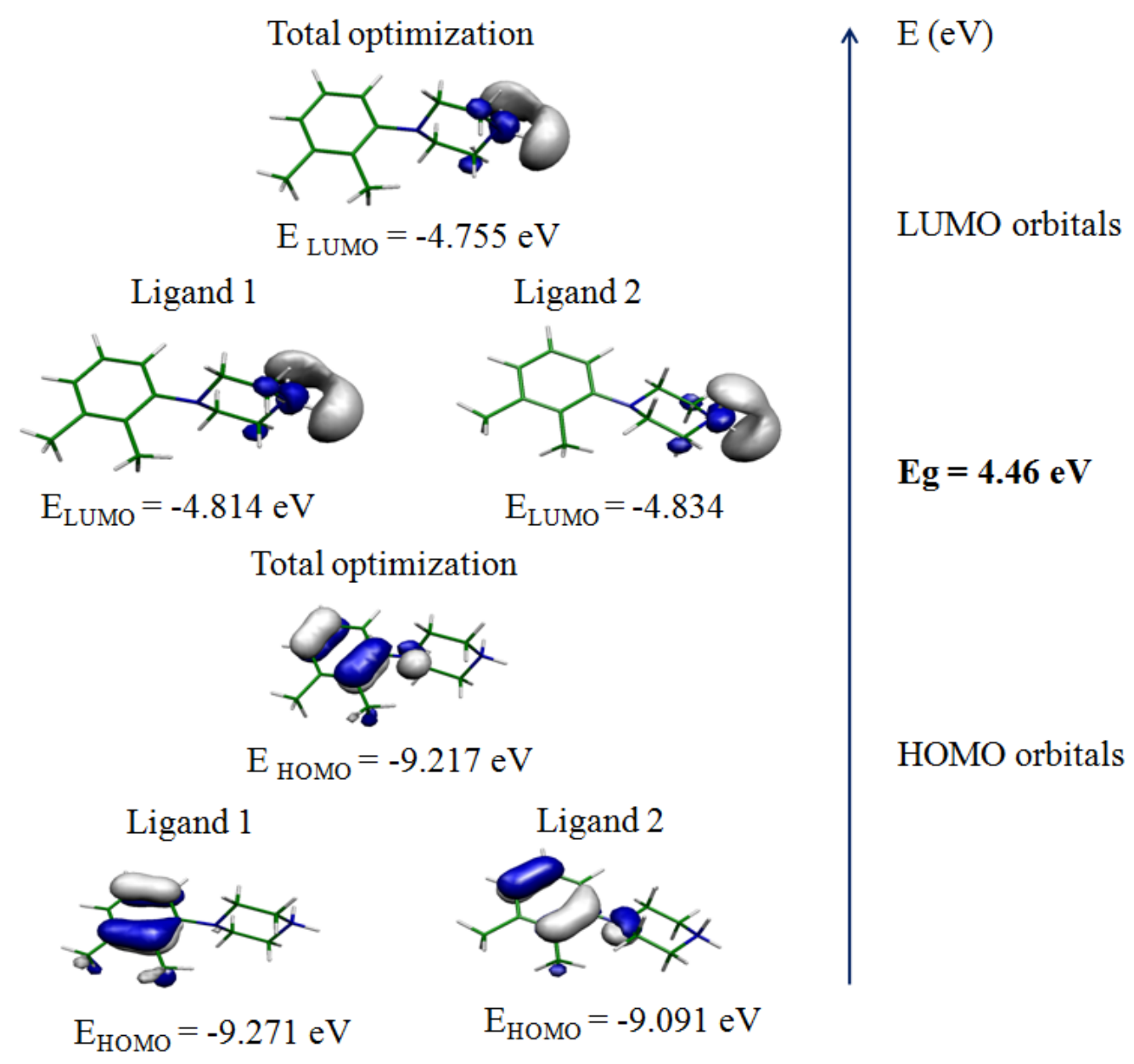

Fig. 6. Frontier molecular orbitals (HOMO and LUMO) for the organic molecule in $\left(\mathrm{C}_{12} \mathrm{H}_{19} \mathrm{~N}_{2}\right)_{4}(\mathrm{Li})_{2}\left(\mathrm{P}_{6} \mathrm{O}_{18}\right)\left(\mathrm{H}_{2} \mathrm{O}\right)_{4}$. 


\section{Total optimization}

Ligand 1

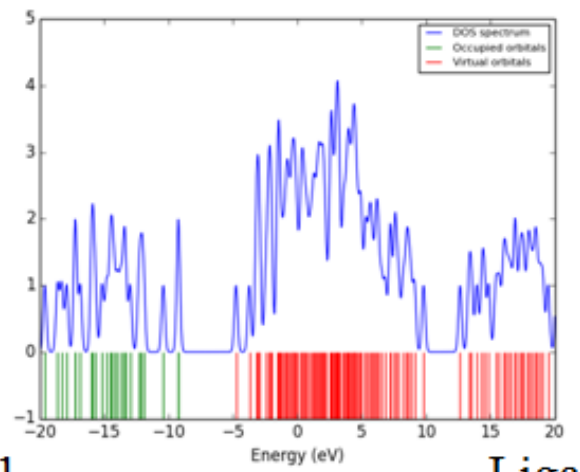

Ligand 2
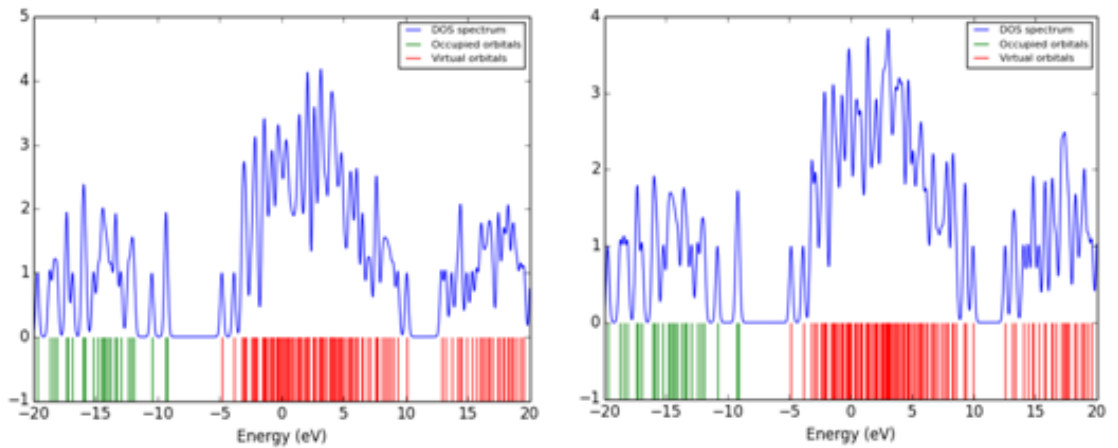

Fig. 7. Energy distribution of the different orbitals for the organic molecule in $\left(\mathrm{C}_{12} \mathrm{H}_{19} \mathrm{~N}_{2}\right)_{4}(\mathrm{Li})_{2}\left(\mathrm{P}_{6} \mathrm{O}_{18}\right)\left(\mathrm{H}_{2} \mathrm{O}\right)_{4}$ 


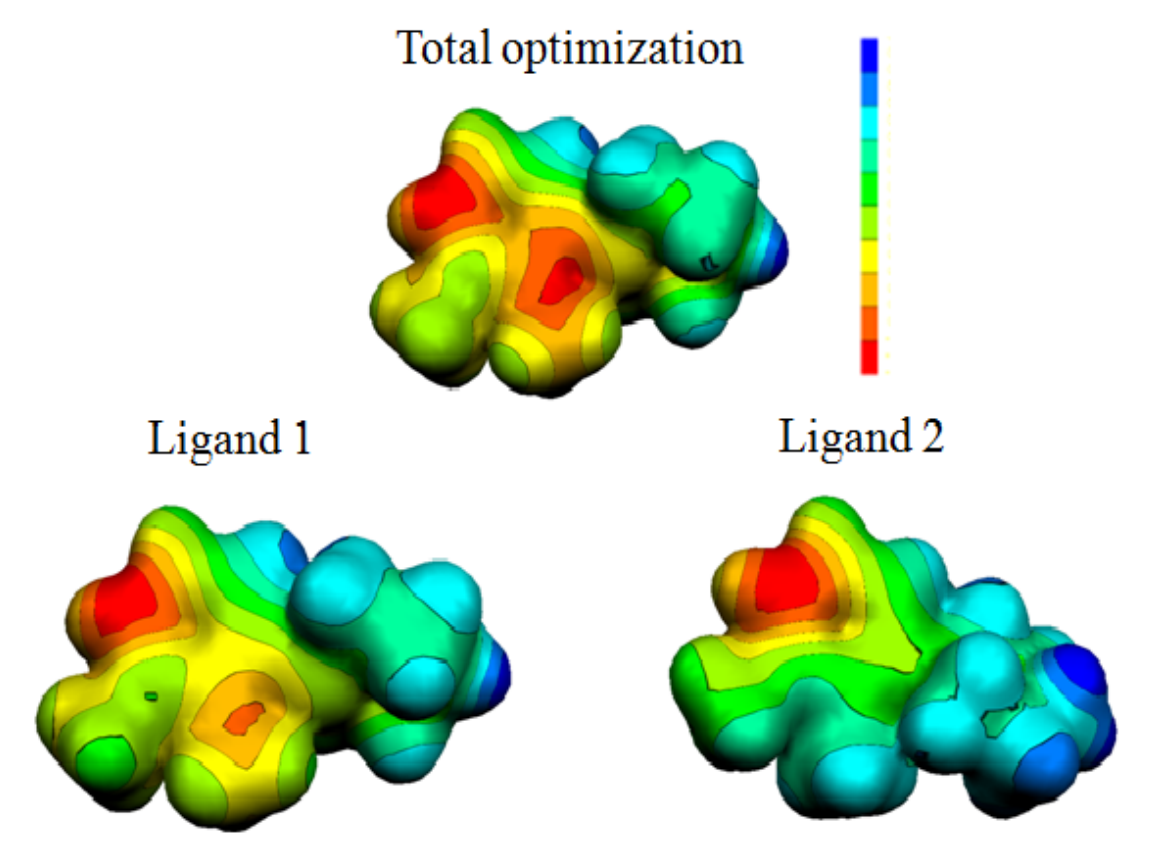

Fig. 8. Molecular Electrostatic Potential maps of the organic molecule in $\left(\mathrm{C}_{12} \mathrm{H}_{19} \mathrm{~N}_{2}\right)_{4}(\mathrm{Li})_{2}\left(\mathrm{P}_{6} \mathrm{O}_{18}\right)\left(\mathrm{H}_{2} \mathrm{O}\right)_{4}$

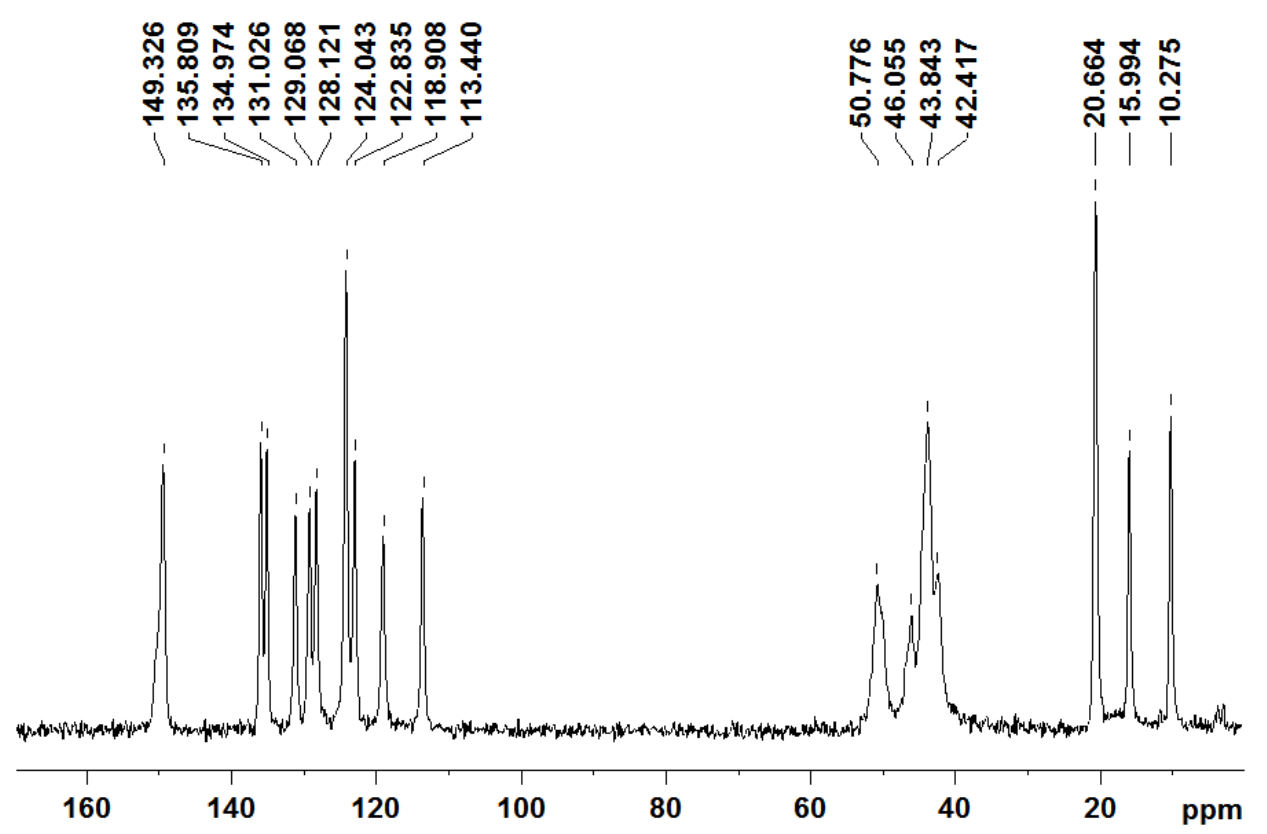

Fig. 9. ${ }^{13} \mathrm{C}$ CP-MAS NMR spectrum of $\left(\mathrm{C}_{12} \mathrm{H}_{19} \mathrm{~N}_{2}\right)_{4}(\mathrm{Li})_{2}\left(\mathrm{P}_{6} \mathrm{O}_{18}\right)\left(\mathrm{H}_{2} \mathrm{O}\right)_{4}$ recorded at a contact time of $2 \mathrm{~ms}$. 


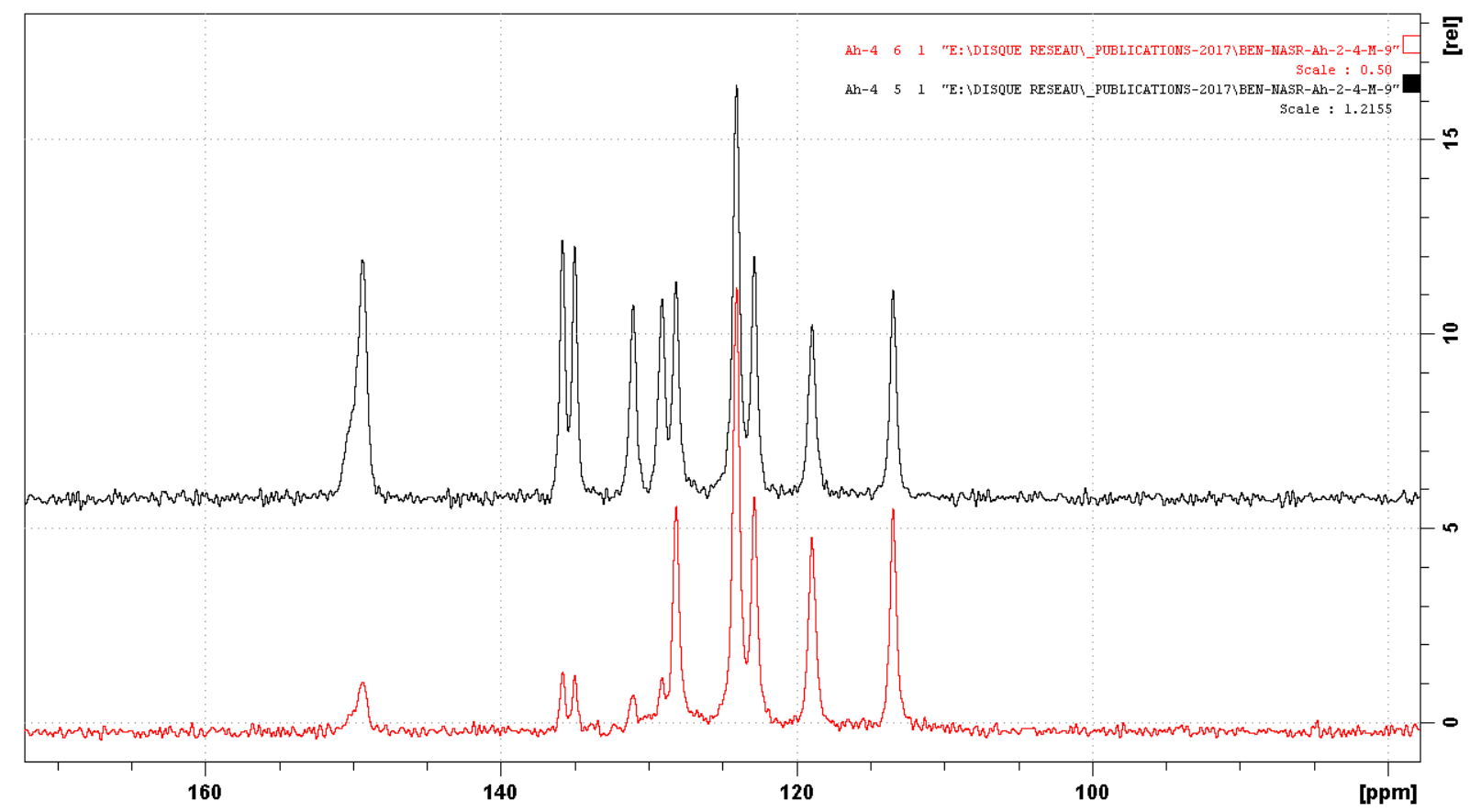

Fig. 10. Resonance zone of the aromatic carbons of the title compound ${ }^{13} \mathrm{C} C \mathrm{CP}-\mathrm{MAS}$ NMR spectrum for a contact time of $2 \mathrm{~ms}$ at the top and $100 \mu \mathrm{s}$ at the bottom.

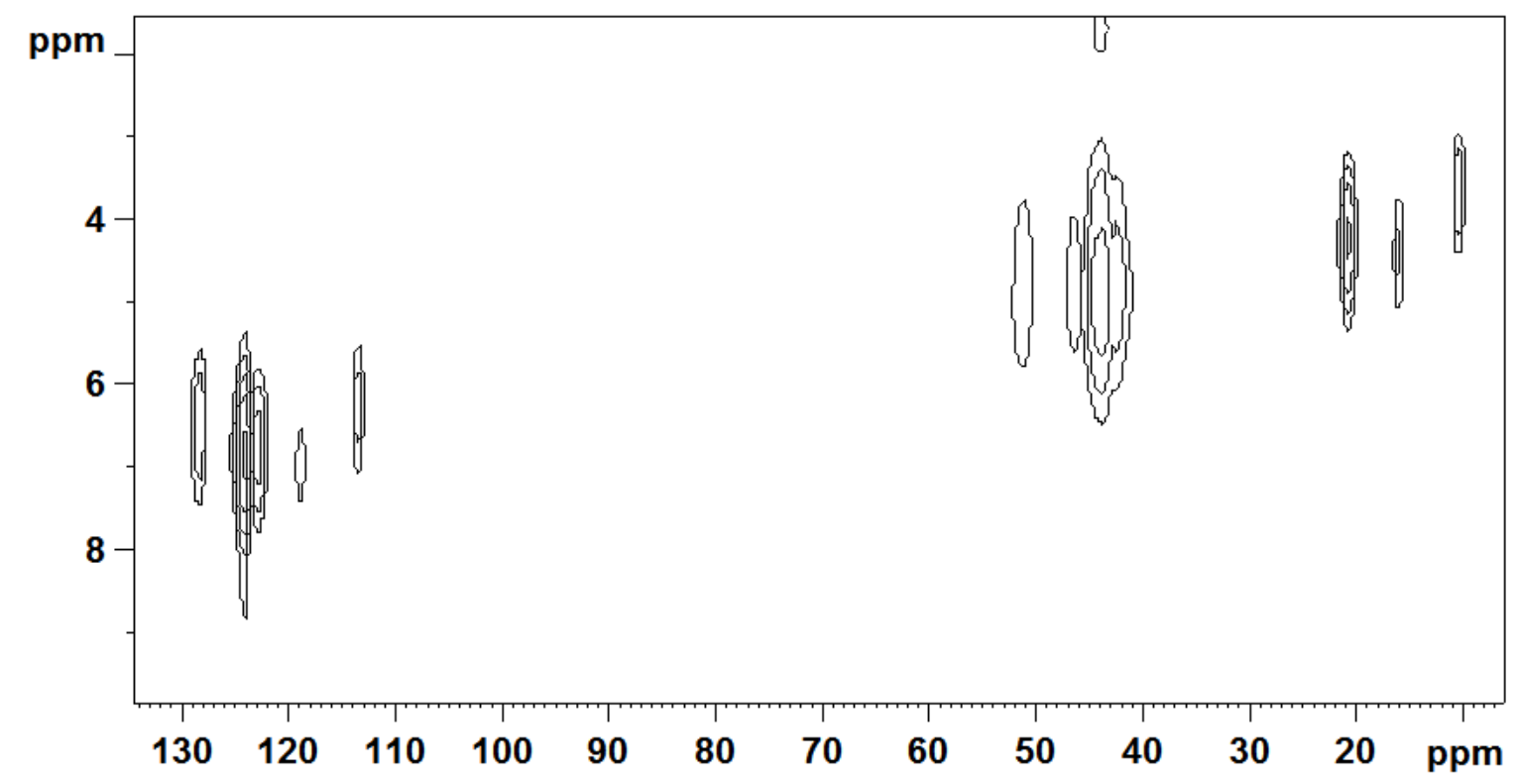

Fig. 11. Two-dimensional carbon- proton spectrum of $\left(\mathrm{C}_{12} \mathrm{H}_{19} \mathrm{~N}_{2}\right)_{4}(\mathrm{Li})_{2}\left(\mathrm{P}_{6} \mathrm{O}_{18}\right)\left(\mathrm{H}_{2} \mathrm{O}\right)_{4}$. 


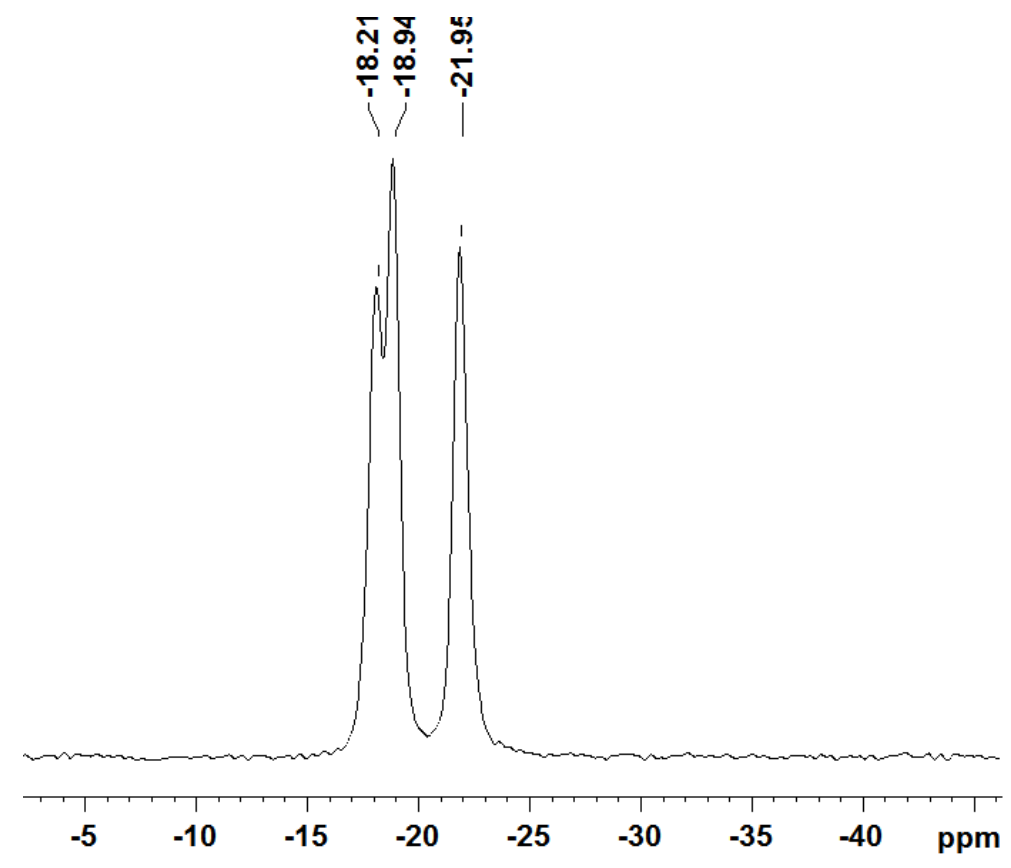

Fig. 12. ${ }^{31} \mathrm{P}$ MAS NMR spectrum of $\left(\mathrm{C}_{12} \mathrm{H}_{19} \mathrm{~N}_{2}\right)_{4}(\mathrm{Li})_{2}\left(\mathrm{P}_{6} \mathrm{O}_{18}\right)\left(\mathrm{H}_{2} \mathrm{O}\right)_{4}$.

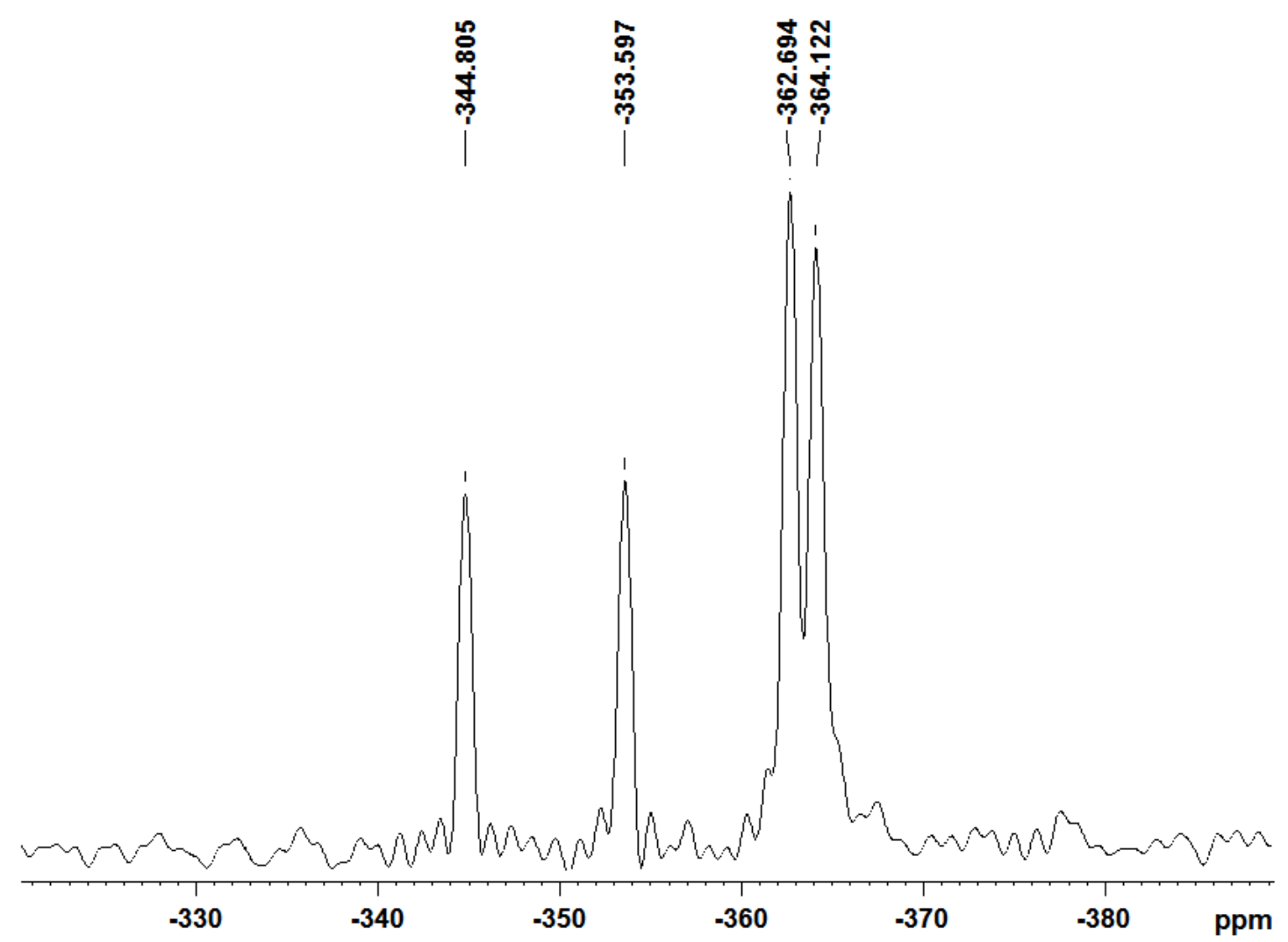

Fig. 13. ${ }^{15} \mathrm{~N}$ CP-MAS NMR spectrum of $\left(\mathrm{C}_{12} \mathrm{H}_{19} \mathrm{~N}_{2}\right)_{4}(\mathrm{Li})_{2}\left(\mathrm{P}_{6} \mathrm{O}_{18}\right)\left(\mathrm{H}_{2} \mathrm{O}\right)_{4}$. 
(a)

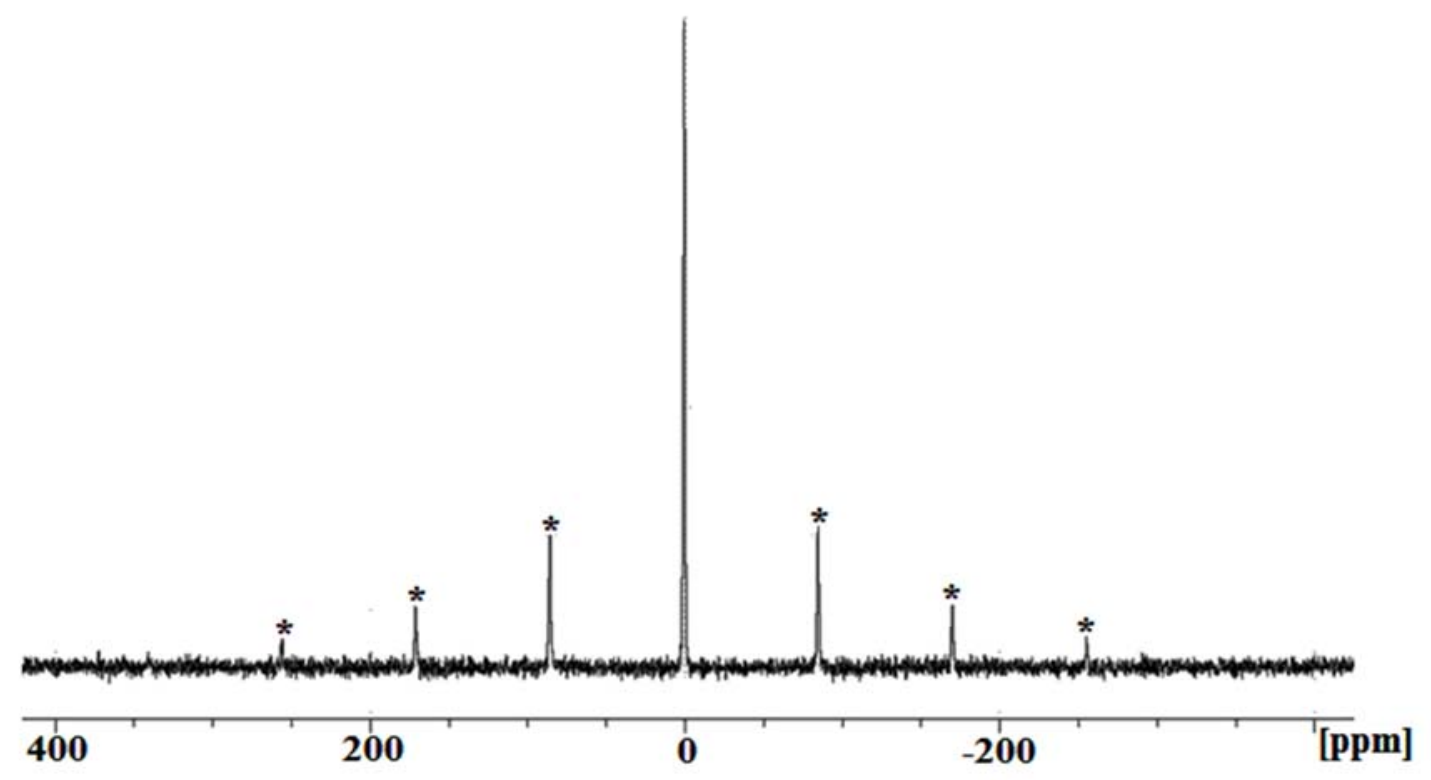

(b)

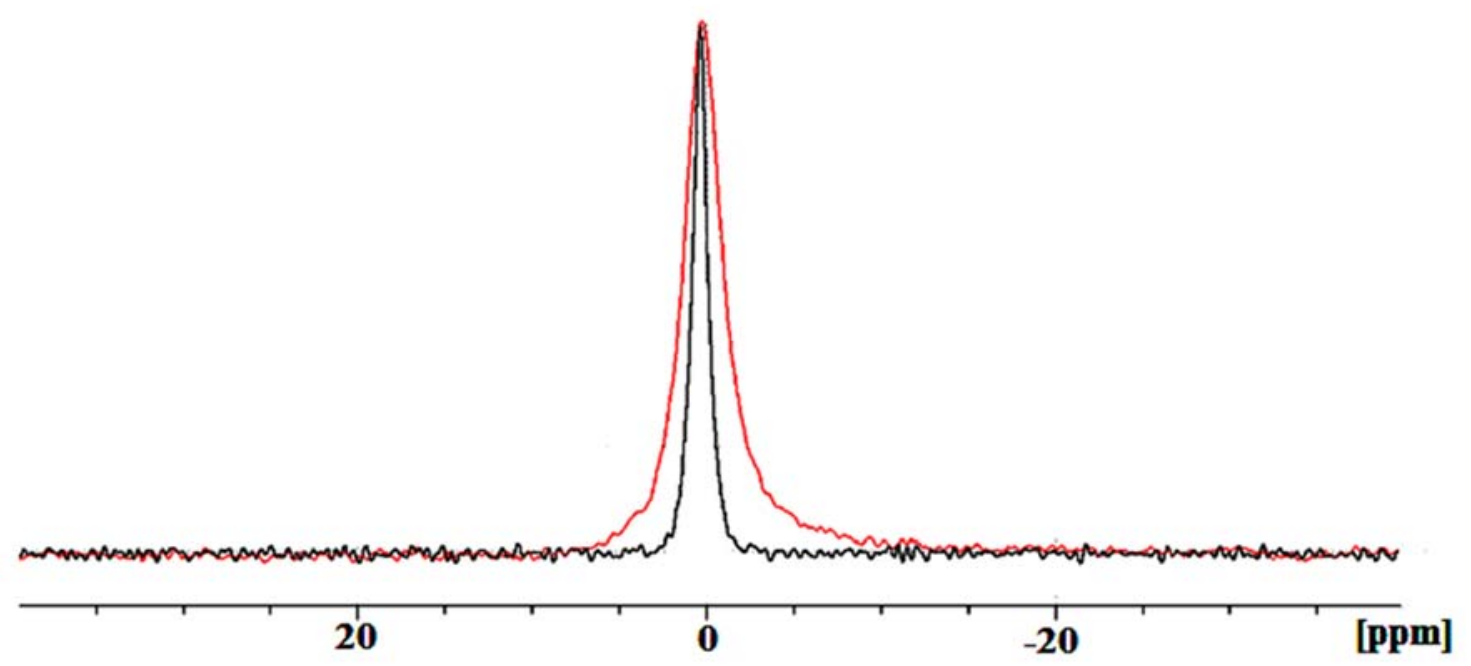

Fig. 14. ${ }^{7} \mathrm{Li}$ MAS NMR spectrum of $\left(\mathrm{C}_{12} \mathrm{H}_{19} \mathrm{~N}_{2}\right)_{4}(\mathrm{Li})_{2}\left(\mathrm{P}_{6} \mathrm{O}_{18}\right)\left(\mathrm{H}_{2} \mathrm{O}\right)_{4}$. 


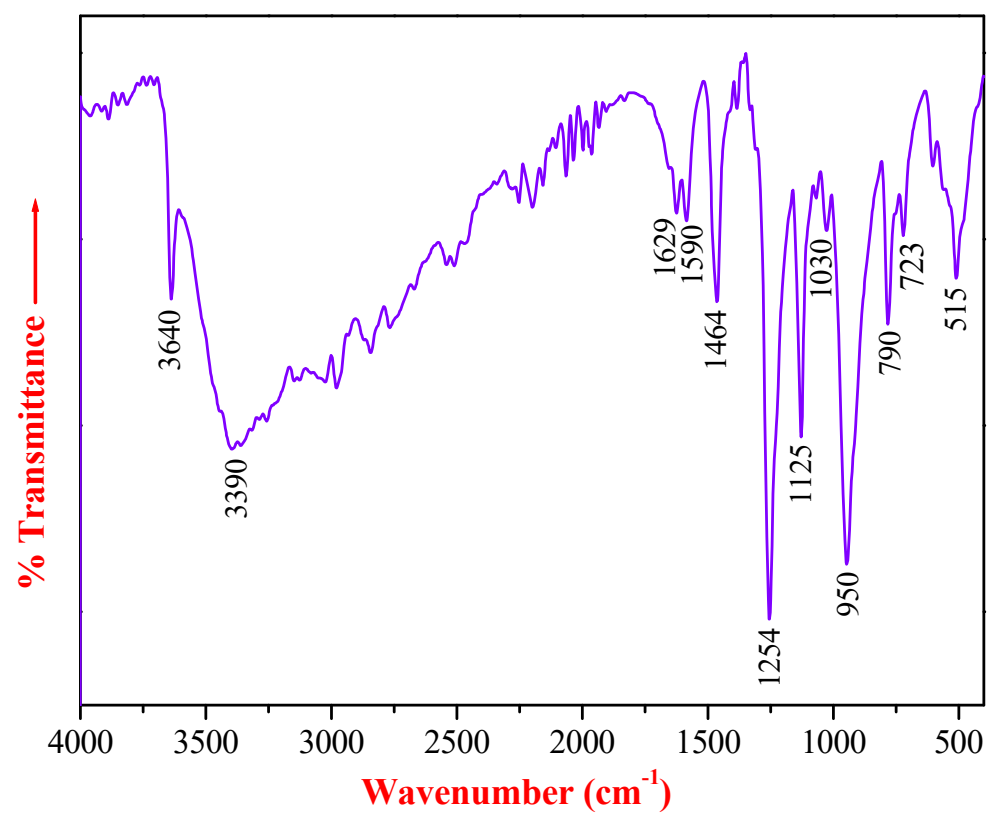

Fig. 15. Infrared spectrum of $\left(\mathrm{C}_{12} \mathrm{H}_{19} \mathrm{~N}_{2}\right)_{4}(\mathrm{Li})_{2}\left(\mathrm{P}_{6} \mathrm{O}_{18}\right)\left(\mathrm{H}_{2} \mathrm{O}\right)_{4}$. 
Table 1. Crystal data and experimental parameters used for the intensity data collection.

Procedure and final results of the structure determination.

Empirical formula

Formula weight $\left[\mathrm{g} \mathrm{mol}^{-1}\right]$

Crystal colour, habit

Crystal temperature $[\mathrm{K}]$

Crystal size $\left[\mathrm{mm}^{3}\right]$

Radiation, wavelength $[\AA]]$

Crystal system

Space group

Unit-cell dimensions:

$a, b, c[\AA]$

$\alpha, \beta, \gamma\left[{ }^{\circ}\right]$

Volume $\left[\AA^{3}\right]$

$Z$

Density calc. $\left[\mathrm{g} \mathrm{cm}^{-3}\right]$

Reflections for cell determination

$\theta$ range for cell determination $\left[^{\circ}\right]$

Absorption coefficient $\mu\left[\mathrm{mm}^{-1}\right]$

$F(000)$

$\theta$-Range for data collection $\left[{ }^{\circ}\right]$

Limiting indices

Reflections collected/unique

Refinement method

Data, restrains, parameters $(\mathrm{I}>2 \sigma)$

Goodness-of-fit on $F^{2}$

$R$ indices (all data, on $F^{2}$ )

$\Delta \rho(\min , \max )\left[\mathrm{e} \AA^{-3}\right]$
$\left(\mathrm{C}_{12} \mathrm{H}_{19} \mathrm{~N}_{2}\right)_{4}(\mathrm{Li})_{2}\left(\mathrm{P}_{6} \mathrm{O}_{18}\right)\left(\mathrm{H}_{2} \mathrm{O}\right)_{4}$

662.46

colourless, rod

295

$0.51 \times 0.20 \times 0.15$

MoKa, 0.71073

triclinic

P-1

$7.398(2) ; 10.301(3) ; 21.699(6)$

$78.629(2) ; 89.825(2) ; 69.879(2)$

$1518.37(8)$

2

1.449

14328

2-27

0.256

700

3.028 to 30.019

$-10 \leq \mathrm{h} \leq 10,-14 \leq \mathrm{k} \leq 14,-29 \leq 1 \leq 30$

$17246 / 6719($ Rint $=0.03)$

Full-matrix least-squares on $F^{2}$

$8405,13,432$

1.052

$R=0.0655, w R=0.1735$

$-0.927,0.970$ 
Table 2. Interatomic distances $(\AA)$ and bond angles $\left({ }^{\circ}\right)$ in $\left(\mathrm{C}_{12} \mathrm{H}_{19} \mathrm{~N}_{2}\right)_{4}(\mathrm{Li})_{2}\left(\mathrm{P}_{6} \mathrm{O}_{18}\right)\left(\mathrm{H}_{2} \mathrm{O}\right)_{4}$. $\mathrm{P}-\mathrm{O}$ distances are on the diagonal, O-P-O angles and O-O distances are above and below the diagonal, respectively.

\section{$\mathrm{P}(1) \mathrm{O}_{4}$ tetrahedron}

\begin{tabular}{|l|c|c|c|c|}
\hline P1 & O1 & O2 & O3 & O4 \\
\hline O1 & $1.476(1)$ & $120.13(8)$ & $110.53(8)$ & $106.25(8)$ \\
\hline $\mathbf{O 2}$ & $2.561(2)$ & $1.479(1)$ & $106.02(8)$ & $110.26(8)$ \\
\hline $\mathbf{O 3}$ & $2.535(2)$ & $2.466(2)$ & $1.607(1)$ & $102.24(7)$ \\
\hline $\mathbf{O 4}$ & $2.476(2)$ & $2.542(2)$ & $2.510(2)$ & $1.617(1)$ \\
\hline
\end{tabular}

$\mathrm{P}(2) \mathrm{O}_{4}$ tetrahedron

\begin{tabular}{|l|c|c|c|c|}
\hline P2 & O3 & O5 & O6 & O7 \\
\hline O3 & $1.601(1)$ & $107.36(8)$ & $112.15(8)$ & $98.53(7)$ \\
\hline O5 & $2.489(3)$ & $1.487(2)$ & $119.33(1)$ & $108.58(8)$ \\
\hline O6 & $2.552(1)$ & $2.554(1)$ & $1.474(2)$ & $108.84(9)$ \\
\hline $\mathbf{O 7}$ & $2.436(2)$ & $2.519(3)$ & $2.513(1)$ & $1.614(1)$ \\
\hline
\end{tabular}

\section{$\mathrm{P}(3) \mathrm{O}_{4}$ tetrahedron}

\begin{tabular}{|l|c|c|c|c|}
\hline P3 & O4 & O7 & O8 & O9 \\
\hline O4 & $1.601(1)$ & $97.23(7)$ & $108.58(8)$ & $110.77(8)$ \\
\hline O7 & $2.409(1)$ & $1.610(1)$ & $109.13(8)$ & $110.37(8)$ \\
\hline O8 & $2.502(4)$ & $2.518(3)$ & $1.478(1)$ & $118.63(9)$ \\
\hline O9 & $2.535(2)$ & $2.537(1)$ & $2.543(1)$ & $1.479(1)$ \\
\hline
\end{tabular}

\section{$\mathrm{Li}(1) \mathrm{O}_{4}$ pentahedron}

\begin{tabular}{|c|c|c|c|c|c|}
\hline Li1 & O2 & O6 & O9 & O9 $^{\mathbf{1}}$ & O1W \\
\hline O2 & $2.018(4)$ & $91.95(15)$ & $136.8(2)$ & $92.07(2)$ & $100.83(2)$ \\
\hline O6 & $3.193(2)$ & $2.406(4)$ & $86.94(2)$ & $170.60(2)$ & $85.49(2)$ \\
\hline O9 & $2.960(2)$ & $3.019(2)$ & $1.956(4)$ & $84.32(2)$ & $122.03(2)$ \\
\hline O9 $^{\mathbf{1}}$ & $3.696(2)$ & $4.485(4)$ & $2.720(1)$ & $2.093(4)$ & $102.08(2)$ \\
\hline O1W & $3.095(4)$ & $3.005(2)$ & $3.461(3)$ & $3.183(3)$ & $2.001(4)$ \\
\hline
\end{tabular}

$\begin{array}{llllll}\text { P1-P2 } & 2.831(2) & \text { P1-O3-P2 } & 131.06(9) & \text { P1-P2-P3 } & 126.89(2) \\ \text { P2-P3 } & 2.920(3) & \text { P1-O4-P3 } & 130.56(9) & \text { P1-P3-P2 } & 137.05(2) \\ \text { P3-P1 } & 2.923(3) & \text { P3-O7-P2 } & 122.80(8) & \text { P2-P1-P3 } & 96.03(2)\end{array}$


Table 3. Interatomic PO distances $(\AA)$, OPO angles $\left(^{\circ}\right)$, tetrahedral distortion indexes ID(PO), ID(OPO) and ID(OO) of $\left(\mathrm{C}_{12} \mathrm{H}_{19} \mathrm{~N}_{2}\right)_{4}(\mathrm{Li})_{2}\left(\mathrm{P}_{6} \mathrm{O}_{18}\right)\left(\mathrm{H}_{2} \mathrm{O}\right)_{4} . \delta$ is the distance between the phosphorus atom and the gravity center of $\mathrm{PO}_{4}$ tetrahedron

\begin{tabular}{|l|l|l|l|l|l|l|l|}
\hline Tetrahedron & $\mathbf{P - O}$ & ID(P-O) & $(\mathbf{O}-\mathbf{P}-\mathbf{O})_{\mathbf{m}}$ & $\mathbf{I D}(\mathbf{O P O})$ & $\mathbf{O - O}$ & ID(O-O) & $\boldsymbol{\delta}(\AA)$ \\
\hline $\mathbf{P ( 1 ) \mathbf { O } _ { 4 }}$ & 1.545 & 0.044 & 109.24 & 0.040 & 2.515 & 0.012 & 0.138 \\
\hline $\mathbf{P ( 2 ) \mathbf { O } _ { 4 }}$ & 1.544 & 0.041 & 109.13 & 0.041 & 2.511 & 0.013 & 0.153 \\
\hline $\mathbf{P ( 3 ) \mathbf { O } _ { 4 }}$ & 1.542 & 0.041 & 109.12 & 0.038 & 2.507 & 0.014 & 0.154 \\
\hline
\end{tabular}


Table 4. Selected bond lengths $(\AA)$ and bond angles $\left(^{\circ}\right)$ in the organic groups of $\left(\mathrm{C}_{12} \mathrm{H}_{19} \mathrm{~N}_{2}\right)_{4}(\mathrm{Li})_{2}\left(\mathrm{P}_{6} \mathrm{O}_{18}\right)\left(\mathrm{H}_{2} \mathrm{O}\right)_{4}$

\begin{tabular}{|c|c|c|c|}
\hline \multicolumn{4}{|c|}{$\left[\mathrm{C}_{12} \mathrm{H}_{19} \mathrm{~N}_{2}(1)\right]^{+}$group } \\
\hline $\mathrm{N} 1-\mathrm{C} 5$ & $1.432(2)$ & C5 - N1 - C1 & $115.43(2)$ \\
\hline $\mathrm{N} 1-\mathrm{C} 1$ & $1.464(3)$ & $\mathrm{C} 5-\mathrm{N} 1-\mathrm{C} 4$ & $112.92(2)$ \\
\hline $\mathrm{N} 1-\mathrm{C} 4$ & $1.473(3)$ & $\mathrm{C} 1-\mathrm{N} 1-\mathrm{C} 4$ & $108.56(2)$ \\
\hline $\mathrm{N} 2-\mathrm{C} 2$ & $1.481(3)$ & $\mathrm{C} 2-\mathrm{N} 2-\mathrm{C} 3$ & $111.14(2)$ \\
\hline $\mathrm{N} 2-\mathrm{C} 3$ & $1.485(3)$ & $\mathrm{C} 17-\mathrm{N} 3-\mathrm{C} 13$ & $115.12(2)$ \\
\hline $\mathrm{C} 1-\mathrm{C} 2$ & $1.507(3)$ & C17 - N3 - C16 & $111.21(2)$ \\
\hline $\mathrm{C} 3-\mathrm{C} 4$ & $1.511(3)$ & $\mathrm{C} 13-\mathrm{N} 3-\mathrm{C} 16$ & $109.61(2)$ \\
\hline $\mathrm{C} 5-\mathrm{C} 10$ & $1.388(3)$ & C14 - N4 - C15 & $111.18(2)$ \\
\hline $\mathrm{C} 5-\mathrm{C} 6$ & $1.409(3)$ & $\mathrm{N} 1-\mathrm{C} 1-\mathrm{C} 2$ & $110.3(2)$ \\
\hline $\mathrm{C} 6-\mathrm{C} 7$ & $1.408(3)$ & $\mathrm{N} 2-\mathrm{C} 2-\mathrm{C} 1$ & $110.66(2)$ \\
\hline C6 - C11 & $1.497(3)$ & $\mathrm{N} 2-\mathrm{C} 3-\mathrm{C} 4$ & $109.4(2)$ \\
\hline $\mathrm{C} 7-\mathrm{C} 8$ & $1.389(3)$ & $\mathrm{N} 1-\mathrm{C} 4-\mathrm{C} 3$ & $110.73(2)$ \\
\hline $\mathrm{C} 7-\mathrm{C} 12$ & $1.514(3)$ & C10 - C5 - C6 & $119.39(2)$ \\
\hline $\mathrm{C} 8$ - C9 & $1.368(4)$ & $\mathrm{C} 10-\mathrm{C} 5-\mathrm{N} 1$ & $121.86(2)$ \\
\hline \multirow[t]{10}{*}{$\mathrm{C} 9$ - C10 } & $1.383(3)$ & $\mathrm{C} 6-\mathrm{C} 5-\mathrm{N} 1$ & $118.75(2)$ \\
\hline & & $\mathrm{C} 7-\mathrm{C} 6-\mathrm{C} 5$ & $118.8(2)$ \\
\hline & & $\mathrm{C} 7$ - C6 - C11 & $119.6(2)$ \\
\hline & & C5 - C6 - C11 & $121.58(2)$ \\
\hline & & $\mathrm{C} 8$ - C7 - C6 & $120.0(2)$ \\
\hline & & $\mathrm{C} 8-\mathrm{C} 7-\mathrm{C} 12$ & $119.1(2)$ \\
\hline & & C6 - C7 - C12 & $120.9(2)$ \\
\hline & & $\mathrm{C} 9-\mathrm{C} 8-\mathrm{C} 7$ & $120.6(2)$ \\
\hline & & $\mathrm{C} 8$ - C9 - C10 & $120.1(2)$ \\
\hline & & $\mathrm{C} 9-\mathrm{C} 10-\mathrm{C} 5$ & $120.9(2)$ \\
\hline \multicolumn{4}{|c|}{$\left[\mathrm{C}_{12} \mathrm{H}_{19} \mathrm{~N}_{2}(2)\right]^{+}$group } \\
\hline N3 - C17 & $1.437(2)$ & N3 - C13 - C14 & $109.23(2)$ \\
\hline N3 - C13 & $1.459(2)$ & N4 - C14 - C13 & $110.12(2)$ \\
\hline N3 - C16 & $1.464(3)$ & N4 - C15 - C16 & $110.3(2)$ \\
\hline N4 - C14 & $1.478(3)$ & N3 - C16 - C15 & $110.6(2)$ \\
\hline N4 - C15 & $1.485(3)$ & $\mathrm{C} 22-\mathrm{C} 17-\mathrm{C} 18$ & $120.47(2)$ \\
\hline $\mathrm{C} 13-\mathrm{C} 14$ & $1.505(3)$ & $\mathrm{C} 22-\mathrm{C} 17-\mathrm{N} 3$ & $121.28(2)$ \\
\hline $\mathrm{C} 15-\mathrm{C} 16$ & $1.507(3)$ & $\mathrm{C} 18-\mathrm{C} 17-\mathrm{N} 3$ & $118.24(2)$ \\
\hline $\mathrm{C} 17-\mathrm{C} 22$ & $1.396(3)$ & C19- C18 - C17 & $118.6(2)$ \\
\hline $\mathrm{C} 17-\mathrm{C} 18$ & $1.406(3)$ & C19 - C18 - C23 & $120.4(2)$ \\
\hline $\mathrm{C} 18-\mathrm{C} 19$ & $1.402(3)$ & $\mathrm{C} 17-\mathrm{C} 18-\mathrm{C} 23$ & $121.0(2)$ \\
\hline $\mathrm{C} 18-\mathrm{C} 23$ & $1.498(3)$ & $\mathrm{C} 20-\mathrm{C} 19-\mathrm{C} 18$ & $119.5(2)$ \\
\hline $\mathrm{C} 19-\mathrm{C} 20$ & $1.389(4)$ & C20 - C19 - C24 & $119.6(2)$ \\
\hline $\mathrm{C} 19-\mathrm{C} 24$ & $1.507(3)$ & $\mathrm{C} 18-\mathrm{C} 19-\mathrm{C} 24$ & $120.9(2)$ \\
\hline $\mathrm{C} 20-\mathrm{C} 21$ & $1.369(4)$ & $\mathrm{C} 21-\mathrm{C} 20-\mathrm{C} 19$ & $121.2(2)$ \\
\hline \multirow[t]{2}{*}{$\mathrm{C} 21-\mathrm{C} 22$} & $1.374(3)$ & $\mathrm{C} 20-\mathrm{C} 21-\mathrm{C} 22$ & $120.5(2)$ \\
\hline & & $\mathrm{C} 21-\mathrm{C} 22-\mathrm{C} 17$ & $119.7(2)$ \\
\hline
\end{tabular}


Table 5. Structural parameters for hydrogen bonding interactions $\left(\AA,^{\circ}\right)$ in $\left(\mathrm{C}_{12} \mathrm{H}_{19} \mathrm{~N}_{2}\right)_{4}(\mathrm{Li})_{2}\left(\mathrm{P}_{6} \mathrm{O}_{18}\right)\left(\mathrm{H}_{2} \mathrm{O}\right)_{4}$

\begin{tabular}{|c|c|c|c|c|}
\hline$D-H \cdots A$ & $D-H$ & $H \cdots A$ & $D \cdots A$ & $D-H \cdots A$ \\
\hline N2 - H...O5 & 0.87 & 1.92 & $2.787(3)$ & 174 \\
\hline $\mathrm{N} 2-\mathrm{H} \ldots \mathrm{O} 8^{\mathrm{i}}$ & 0.87 & 2.04 & $2.811(3)$ & 147 \\
\hline $\mathrm{N} 4-\mathrm{H} \ldots \mathrm{O} 2^{\mathrm{ii}}$ & 0.87 & 2.15 & $3.008(3)$ & 169 \\
\hline $\mathrm{N} 4-\mathrm{H} \ldots \mathrm{O} 1^{\mathrm{iii}}$ & 0.96 & 1.87 & $2.792(3)$ & 163 \\
\hline $\mathrm{O} 1 \mathrm{~W}-\mathrm{H} \ldots \mathrm{O} 4^{\text {iv }}$ & 0.84 & 2.43 & $3.085(2)$ & 136 \\
\hline $\mathrm{O} 1 \mathrm{~W}-\mathrm{H} \ldots \mathrm{O} 7^{\mathrm{v}}$ & 0.84 & 2.44 & $3.232(2)$ & 157 \\
\hline $\mathrm{O} 1 \mathrm{~W}-\mathrm{H} \ldots \mathrm{O} 2 \mathrm{~W} 1^{\mathrm{v}}$ & 0.86 & 2.02 & $2.876(11)$ & 171 \\
\hline $\mathrm{O} 1 \mathrm{~W}-\mathrm{H} \ldots \mathrm{O} 2 \mathrm{~W} 2^{\mathrm{v}}$ & 0.86 & 1.85 & $2.689(8)$ & 165 \\
\hline $\mathrm{O} 2 \mathrm{~W} 1-\mathrm{H} . . . \mathrm{O}^{\mathrm{ii}}$ & 0.85 & 2.14 & $2.993(8)$ & 177 \\
\hline $\mathrm{O} 2 \mathrm{~W} 2-\mathrm{H} \ldots \mathrm{O} 8^{\mathrm{vi}}$ & 0.84 & 1.86 & $2.702(8)$ & 176 \\
\hline $\mathrm{C} 4-\mathrm{H} \ldots \mathrm{O} 3$ & 0.97 & 2.62 & $3.386(3)$ & 135 \\
\hline C4 - H...O66 vii & 0.97 & 2.65 & $3.456(3)$ & 140 \\
\hline
\end{tabular}

Equivalent positions: i) 1-x,1-y,1-z; ii) $\mathrm{x}, \mathrm{y}-1, \mathrm{z}$; iii) $\mathrm{x}-1, \mathrm{y}-1, \mathrm{z}$; iv) 1-x,2-y,1-z;

v) $\mathrm{x}, \mathrm{y}+1, \mathrm{z}$; vi ) $2-\mathrm{x}, 1-\mathrm{y}, 1-\mathrm{z}$; vii) $\mathrm{x}-1, \mathrm{y}, \mathrm{z}$ 
Table 6. Chemical content (\%) on the Hirshfeld surface, Cxy (\%) contact types and their enrichment ratios Exy. $\mathrm{N}$ chemical species, whose content is only $0.5 \%$ on the surface, was omitted. The major interaction types and the most enriched are in bold. The hydrogen atoms ( $\mathrm{Ho} / \mathrm{n}$ and, $\mathrm{Hc}$ ) bound to $\mathrm{O} / \mathrm{N}$ and $\mathrm{C}$ are distinguished, as their interaction properties are different.

\begin{tabular}{|c|ccccc|cc|}
\hline atom & $\mathrm{Li}$ & $\mathrm{Ho} / \mathrm{n}$ & $\mathrm{O}$ & $\mathrm{P}$ & $\mathrm{N}$ & $\mathrm{Hc}$ & $\mathrm{C}$ \\
\hline \%surface & 7.4 & 17.0 & 20.9 & 5.9 & 0.5 & 38.0 & 10.4 \\
\hline $\mathrm{Li}$ & 0.3 & & & & & & \\
$\mathrm{Ho} / \mathrm{n}$ & 1.3 & 3.0 & & & & $\mathrm{Cxy}$ & \\
$\mathrm{O}$ & $\mathbf{1 0 . 8}$ & $\mathbf{1 9 . 0}$ & 0.4 & & & & \\
$\mathrm{P}$ & 1.3 & 3.4 & 0.1 & 0.0 & & & \\
\hline $\mathrm{Hc}$ & 0.8 & 4.3 & $\mathbf{9 . 6}$ & 6.7 & 0.5 & $\mathbf{1 9 . 8}$ & \\
$\mathrm{C}$ & 0.0 & 0.0 & 1.2 & 0.5 & 0.1 & $\mathbf{1 4 . 6}$ & 2.2 \\
\hline $\mathrm{Li}$ & 0.70 & & & & & & \\
$\mathrm{Ho} / \mathrm{n}$ & 0.54 & 1.04 & & & & & \\
$\mathrm{O}$ & $\mathbf{3 . 2}$ & $\mathbf{2 . 7}$ & 0.10 & & & & \\
$\mathrm{P}$ & 1.31 & 1.66 & 0.02 & 0.00 & & & \\
\hline $\mathrm{Hc}$ & 0.14 & 0.33 & 0.60 & 1.45 & 1.52 & $\mathbf{1 . 3 8}$ & $\mathbf{2 . 0}$ \\
$\mathrm{C}$ & 0.01 & 0.00 & 0.28 & 0.38 & 0.94 & $\mathbf{1 . 8 4}$ & \\
\hline
\end{tabular}


Table 7. Comparison of calculated and experimental chemical shift values (ppm) of the carbon and nitrogen atoms in the title cyclohexaphosphate.

\begin{tabular}{|c|c|c|c|c|}
\hline Atoms & Full optimisation & Ligand 1 & Ligand 2 & Experiment \\
\hline $\mathrm{C} 1$ & 140.8 & 138.9 & 137.9 & 149.3 \\
\hline $\mathrm{C} 2$ & 128.2 & 126.6 & 124.5 & 131.0 \\
\hline $\mathrm{C} 3$ & 138.7 & 136.4 & 137.2 & $135.8 / 135.0$ \\
\hline $\mathrm{C} 4$ & 126.5 & 123.0 & 121.7 & $129.1 / 128.1$ \\
\hline $\mathrm{C} 5$ & 123.8 & 119.4 & 120.2 & $124.0 / 122.0$ \\
\hline C6 & 112.2 & 108.1 & 105.2 & 113.118 .9 \\
\hline $\mathrm{C} 7$ & 23.2 & 23.3 & 23.2 & 20.7 \\
\hline $\mathrm{C} 8$ & 14.8 & 13.9 & 16.0 & $10.3 / 16.0$ \\
\hline C9 & 52.9 & 53.2 & 48.6 & \multirow{4}{*}{$\begin{array}{c}\text { Peak at } 50.8 \\
\text { for the two } \\
\text { signals } \\
\text { calculated } \\
\text { at } 52.2 \text { et } \\
53.2\end{array}$} \\
\hline $\mathrm{C} 10$ & 50.4 & 46.2 & 45.5 & \\
\hline $\mathrm{C} 11$ & 50.0 & 49.6 & 52.2 & \\
\hline $\mathrm{C} 12$ & 51.3 & 45.8 & 45.8 & \\
\hline N1 & 200.1 & 200.0 & 190.8 & $\begin{array}{c}-344.8 \&- \\
353.6\end{array}$ \\
\hline $\mathrm{N} 2$ & 205.1 & 206.0 & 206.2 & $\begin{array}{c}-362.7 \&- \\
364.1\end{array}$ \\
\hline
\end{tabular}

